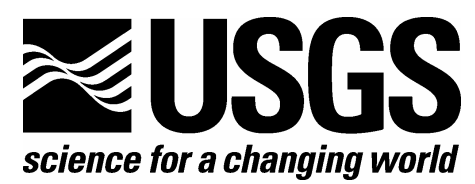

Pacific Island Ecosystems Research Center

Final Integrated Trip Report-Site Visits to Area 50, Andersen Air Force Base, Guam National Wildlife Refuge, War in the Pacific National Historical Park, Guam, Rota and Saipan, CNMI, 2004-2005

By Steven C. Hess and Linda W. Pratt

2006

Open-File Report 2005-1299 


\section{U.S. Department of the Interior \\ DIRK KEMPTHORNE, Secretary}

\section{U.S. Geological Survey \\ Mark D. Myers, Director}

\section{U.S. Geological Survey, Reston, Virginia 2006}

For product and ordering information:

World Wide Web: http://www.usgs.gov/pubprod

Telephone: 1-888-ASK-USGS

For more information on the USGS - the Federal source for science about the Earth, its natural and living resources, natural hazards, and the environment:

World Wide Web: http://www.usgs.gov

Telephone: 1-888-ASK-USGS

Suggested citation:

Hess, S.C. and Pratt, L.W., 2006, Final Integrated Trip Report-Site Visits to Area 50, Andersen Air Force Base, Guam National Wildlife Refuge, War in the Pacific National Historical Park, Guam, Rota and Saipan, CNMI, 2004-2005: U.S. Geological Survey Open-File Report 2005-1299 [available on the World Wide Web at URL http://pubs.usgs.gov/of/2005/1299 ].

Any use of trade, product, or firm names is for descriptive purposes only and does not imply endorsement by the U.S. Government.

Although this report is in the public domain, permission must be secured from the individual copyright owners to reproduce any copyrighted material contained within this report. 


\section{Contents}

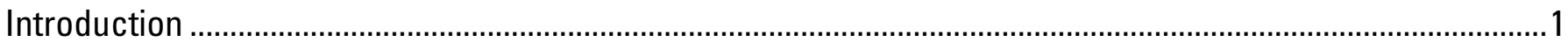

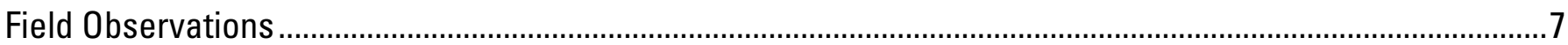

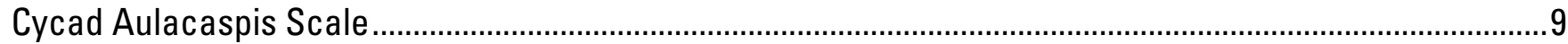

NPS Units of War in the Pacific National Historical Park (WAPA) ...............................................................

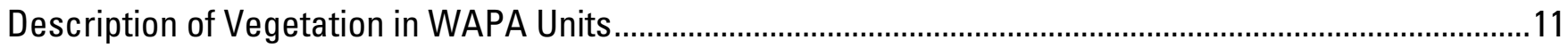

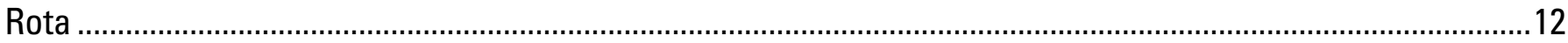

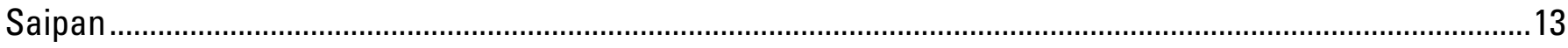

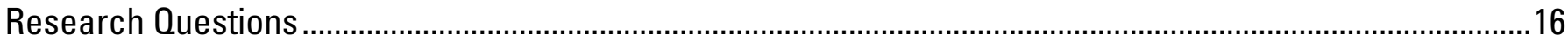

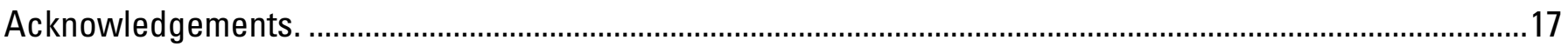

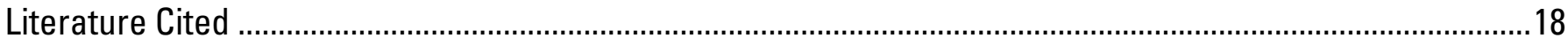

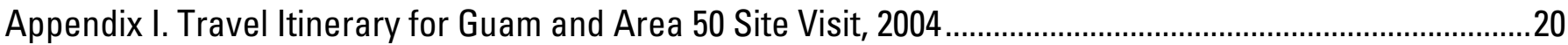

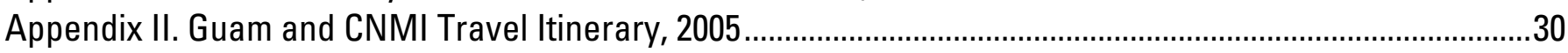

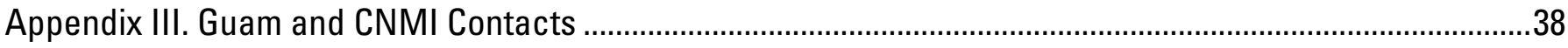

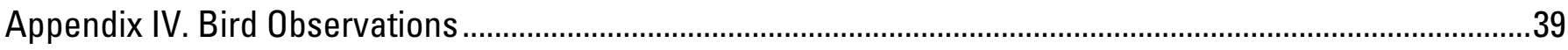

Appendix V. Preliminary checklist of vascular plants at War in the Pacific National Historical Park............40

Appendix VI. Vascular plant checklist additions to American Memorial Park.............................................49

\section{Figures}

Figure 1. Guam and the Mariana islands of Rota, Agiguan, Tinian, and Saipan.

Figure 2. The distribution of primary and secondary limestone forests, other plant communities, roads, airfields (gray), and developed areas (stippled) at Andersen Air Force Base, Northern Guam......

Figure 3. Multi-spectral IKONOS imagery and administrative boundaries (red) of Northwest Field and Ritidian Point

Figure 4. Digital Orthographic Photo imagery of Area 50, Andersen Air Force Base.........................................6

Figure 5. Height distribution of 51 Elaeocarpus joga seedlings found under 3 mature tree canopies in Area 50, Andersen Air Force Base, Guam, May 2004.

Figure 7. Approximate boundaries of conservation lands on the Island of Rota, Commonwealth of the Northern Mariana Islands

Figure 8. Approximate boundaries of conservation lands, natural areas, and U.S. National Parks of Northern Saipan, Commonwealth of the Northern Mariana Islands.

Figure 9. Digital Orthographic Photo imagery and American Memorial Park, Saipan, showing location of wetlands. 


\title{
Final Integrated Trip Report-Site Visits to Area 50, Andersen Air Force Base, Guam National Wildlife Refuge, War in the Pacific National Historical Park, Guam, Rota and Saipan, CNMI, 2004-2005
}

\author{
By Steven C. Hess and Linda W. Pratt'
}

\section{Introduction}

Limestone forests are the most diverse natural plant communities of Guam. Like other natural vegetation types, these forests have a long history of anthropogenic disturbances, being altered and shaped by humans for more than 4,000 years (Athens and Ward, 2004). Although this occupation represents a relatively long human influence in comparison to other Pacific islands, animals associated with humans, such as commensal rodents, arrived in these islands beginning only 1,000 years ago, and larger mammals, such as pigs (Sus scrofa), may not have arrived until European contact (Steadman, 1999). Limestone forests, which also occur on several other Mariana Islands, developed in the presence of frequent tropical storms and are therefore well adapted to this type of natural disturbance regime. However, recent human activities including large scale clearing and conversion combined with the presence of high levels of alien herbivores and seed predators, and the loss of ecological services provided by the former native avifauna may be causing the decline of Guam's forests. Limestone forests on northern Guam, much like those of other Mariana Islands, were heavily cleared for the construction of military installations during World War II (fig. 1). The accidental introduction of the Brown Tree Snake (Boiga irregularis; BTS) around this same period subsequently accelerated the disappearance of Guam's native avifauna and other endemic terrestrial vertebrates (Savidge, 1987), and with them, seed dispersal, pollination, and the predatory regulation of herbivorous insects.

Guam and the Mariana Islands contained a high proportion (32\%) pecent) of endemic bird species (Baker, 1951), with 4 forms endemic to Guam alone: the now extinct Guam Flycatcher (Myiagra freycineti), and Guam Bridled White-eye (Zosterops conspicillata conspicillata), one of three island endemic subspecies from the Marianas; Guam rail (Rallus owstonii); and Guam Kingfisher (Todiramphus cinnamominus cinnamominus), an island endemic subspecies of the regionally endemic Micronesian Kingfisher. Guam once supported the Mariana Gallinule (Gallinula chloropus guami), the Mariana Mallard (Anas platyrhynchos oustaleti), Mariana FruitDove (Ptilinopus roseicapilla), White-throated Ground Dove (Gallicolumba xanthonura xanthonura), Mariana Crow (Corvus kubaryi), and the Nightingale Reed-warbler (Acrocephalus luscinia), all endemic to the Mariana Islands. Other regionally endemic endangered species include the Micronesian Megapode (Megapodius laperouse), and the Mariana Swiftlet (Aerodramus bartschi), now reduced to a small population on Guam.

\footnotetext{
${ }^{1}$ USGS Pacific Island Ecosystems Research Center, Kilauea Field Station, POB 44, HNP, HI 96718
} 
Likewise, the flora of Guam is unique, with $21 \%$ of its native vascular plants endemic to the Mariana Islands (Fosberg, 1960; Stone, 1970). In limestone forests of Northern Guam, a number of tall forest tree species such as joga, Elaeocarpus joga (Elaeocarpaceae); pengua or Macaranga thompsonii (Euphorbiaceae); ifit or Intsia bijuga (Fabaceae); seeded breadfruit or Artocarpus marianensis (Moraceae); and umumu or Pisonia grandis (Nyctaginaceae) may be in decline as a result of herbivory by mammals. All show reduced regeneration and age distributions highly skewed towards older individuals (Schreiner, 1997; Ritter and Naugle, 1999). These species provided important habitat for some of Guam's endangered forest birds that remain in captivity such as the Mariana Crow, Guam Kingfisher, and Guam Rail. The recent high frequency of intense tropical storms and herbivory caused by large populations of feral pigs and Philippine sambar deer (Cervus mariannus), as well as invasive alien vines that may suppress tree regeneration, could be permanently altering the structure of regenerating forests and composition of important canopy species on secondary limestone substrates that were cleared and compacted during airfield construction from 1944 through the 1970s (figs. 2 and 3). Guam National Wildlife Refuge (GNWR) was established at Ritidian Point, after it was determined to be excess property by the U.S. Navy. Most of the refuge, about 9,087 hectares, is an "overlay refuge" on lands administered by the U.S. Air Force and U.S. Navy (U.S. Fish and Wildlife Service, 1995). Although the military mission comes first on these lands, the U.S. Fish and Wildlife Service assists in protecting native species and habitats. The recovery of limestone forest on Guam for forest bird habitat may require intensive management, including reduction of feral herbivores, propagation, out-planting, weed control, and periodic suppression of herbivorous insects. Research to support these techniques may be best accomplished in small areas where potential limiting factors can easily be experimentally manipulated.

Area 50, a 24 ha enclosure, contains a relictual patch of relatively undisturbed limestone forest surrounded by tarmac allowing easy access and management opportunities to control alien mammals and snakes (fig. 4). These species have been periodically managed in the past, but recent typhoons have damaged snake-proofing on the enclosure fence. A new concrete barrier is planned to provide more permanent control opportunities within this enclosed area or another similar area, thereby allowing experimental research for various management regimes (Perry et al., 1999). Eradication and control of alien vertebrate and plant pests will provide habitat where native communities can be restored in a small, intensively managed area. The stated aim of this project is to "affect ecosystem restoration through the removal and exclusion of introduced species and the reestablishment and propagation of native species, with focus on the reintroduction of native forest bird species." This will be achieved by constructing a multispecies barrier surrounding the area, coordinated eradication of selected alien species within the area, and possible reintroduction of Mariana Crow, Guam Kingfisher, and Guam Rail. This barrier also allows experimental research questions to be addressed within the small enclosure around Area 50 that may be applied to manage and restore the larger areas of limestone forest on northern Guam and also similar forests on other islands of the Marianas. 

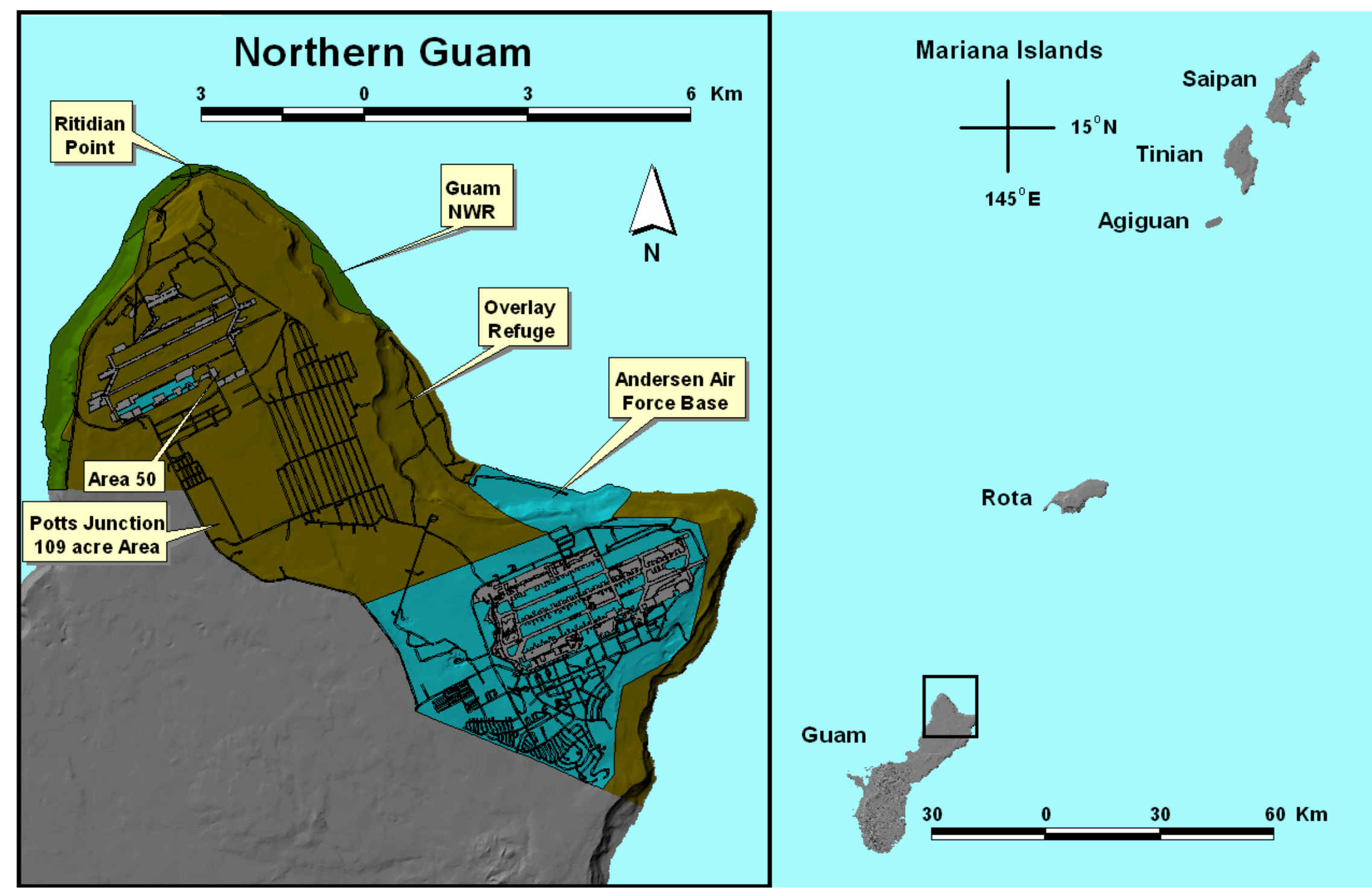

Figure 1. Guam and the Mariana Islands of Rota, Agiguan, Tinian, and Saipan. Inset of Northern Guam with Guam National Wildlife Refuge (headquartered at Ritidian Point), Andersen Air Force Base, overlay refuge, Area 50, and the Potts Junction 109 acre area. 


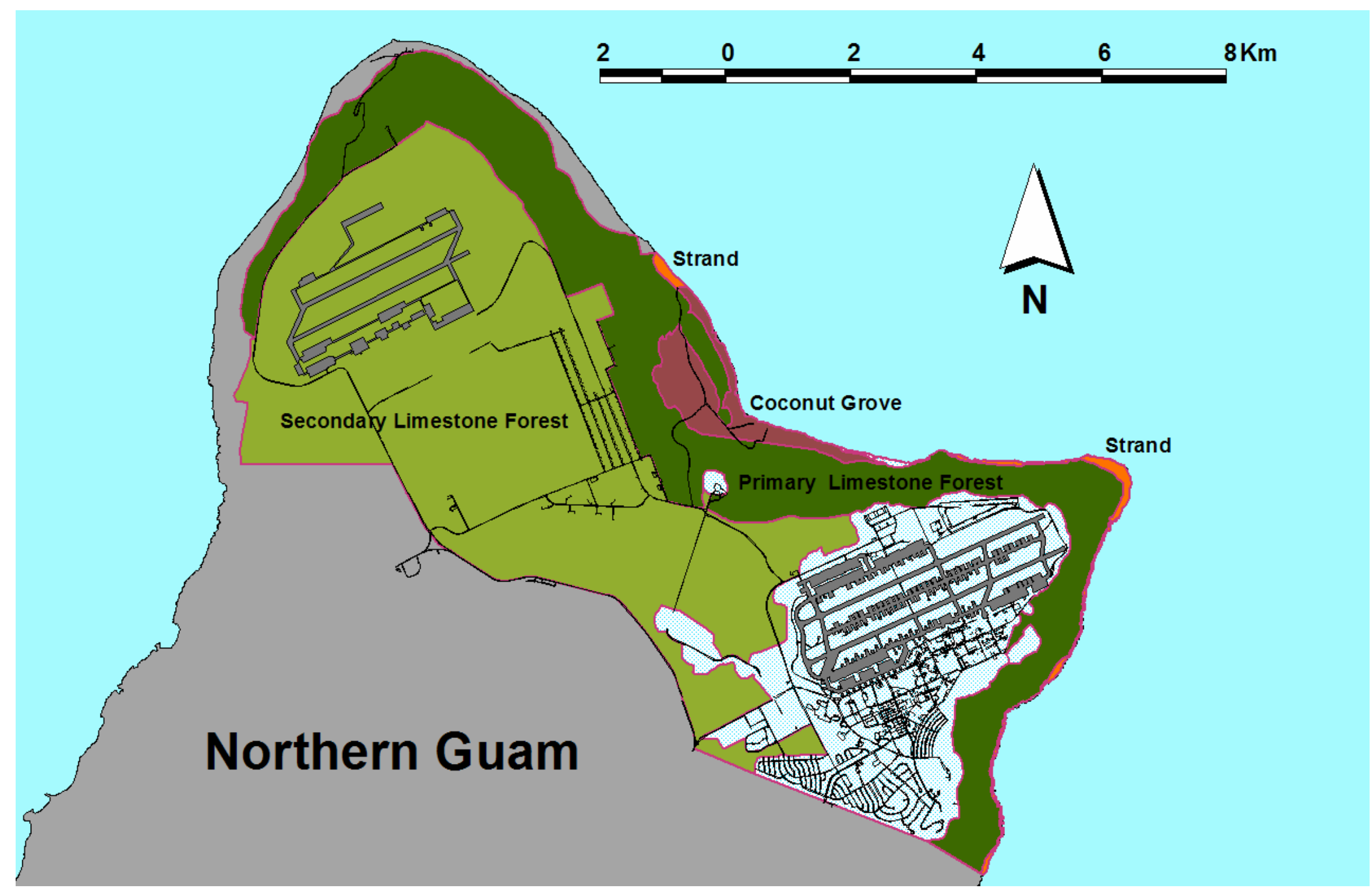

Figure 2. The distribution of primary and secondary limestone forests, other plant communities, roads, airfields (gray), and developed areas (stippled) at Andersen Air Force Base, Northern Guam. 


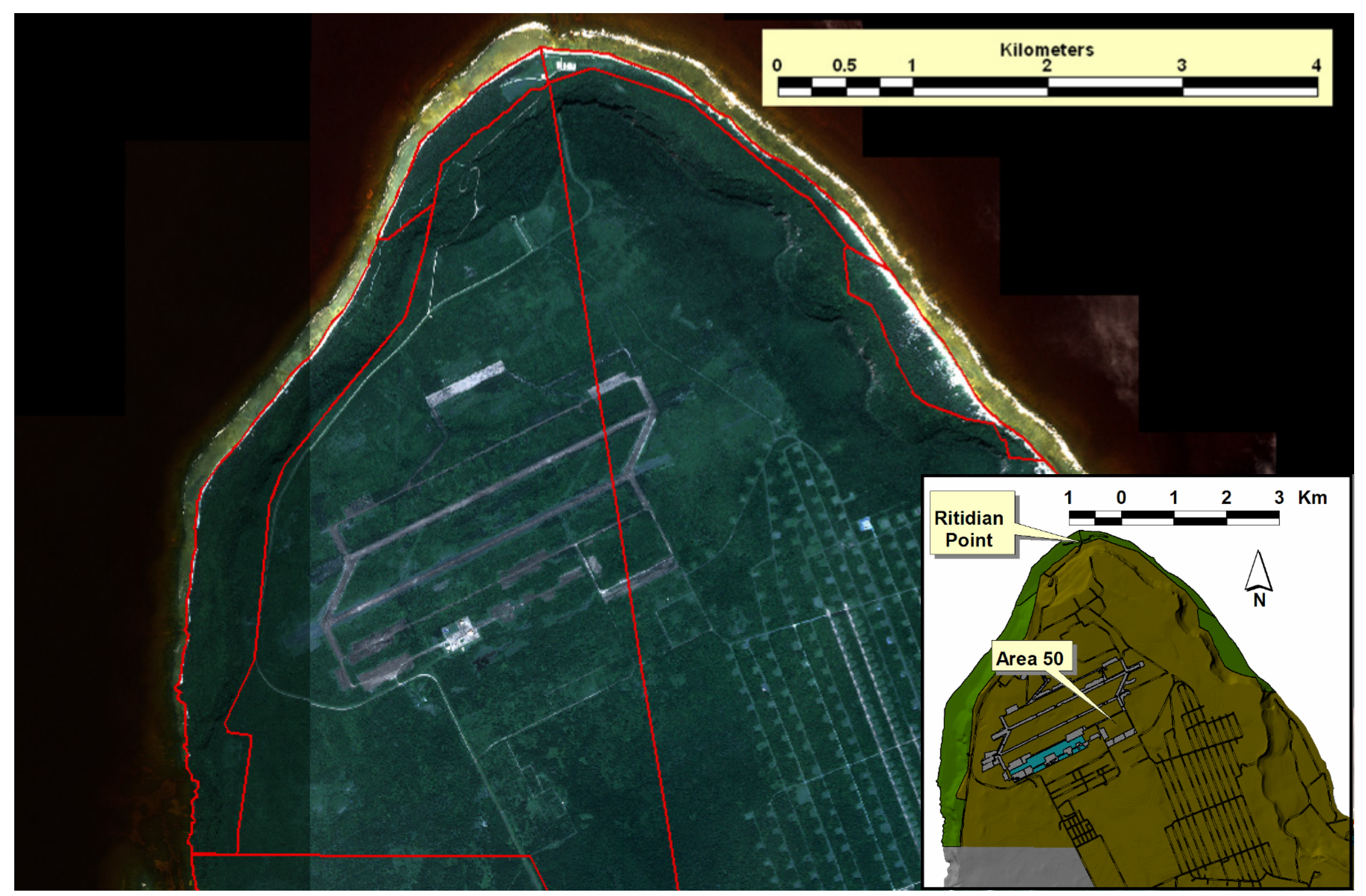

Figure 3. Multispectral IKONOS imagery and administrative boundaries (red) of Northwest Field and Ritidian Point. Previously cleared areas appear as lighter shades of green, and primary forest appears darker. 


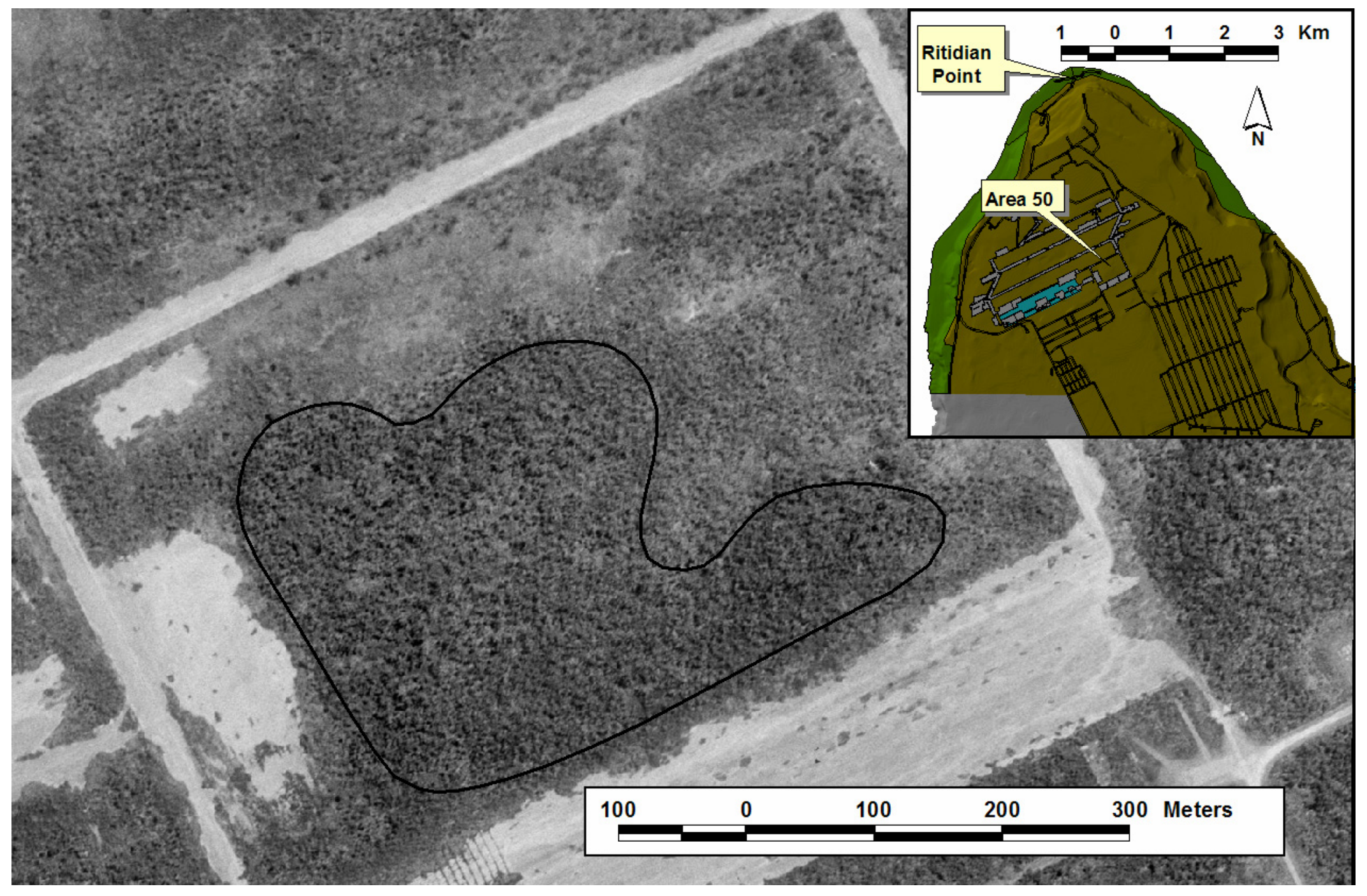

Figure 4. Digital Orthographic Photo imagery of Area 50, Andersen Air Force Base. Outline indicates approximate area of greatest forest development, $74,138 \mathrm{~m}^{2}$, or roughly $30 \%$ of the enclosed vegetation. 
A considerable knowledge base on plant communities in Area 50 and surrounding limestone forests of Ritidian Point and northern Guam already exists. Morton et al. (1998, 2000) reported baseline vegetation structure, composition, and a design for monitoring herbivore removal in Area 50. Patterns of forest regeneration after different disturbance regimes have also been documented for Guam with implications for herbivore removal and the absence of avian seed dispersers (Perry and Morton, 1999). Extensive floristic surveys have been conducted for plants on the sea cliff faces at Ritidian Point and on Andersen Air Force Base (Perlman and Wood, 1994; Quinata, 1994). Rare plants such as Solanum guamense (Solanaceae) and several stands of lookingglass tree or Heritiera longipetiolata (Sterculiaceae), a species recognized as endangered by the Government of Guam, have been reported from limestone cliffs of Andersen Air Base (Perlman and Wood, 1994). Several specimens of the rare endemic Tabernaemontana rotensis (Apocynaceae), a limestone forest specialist, have also been found in area 50 (Morton et al., 2000). Another tree that also provides important habitat structure for wildlife, faniok or Tristiropsis obtusangula (Sapindaceae), is a co-dominant tree in Area 50 (Schreiner, 1997). The most critically endangered tree of Guam and the Marianas, Serianthes nelsonii (Fabaceae), locally known as hayun lagu or fire tree, has been reduced to one mature individual on Guam and a small number on Rota (USFWS, 1994). This tree will not recover without immediate active propagation and protection (Wiles et al., 1996).

Suspected factors that limit recovery of limestone forests fall into 3 general categoriespast land-use patterns, disturbance and damage by herbivorous mammals, and cascading ecological effects from the loss of seed dispersers, pollinators, and insect predators. These factors may also interact with external factors such as typhoons, possibly causing the proliferation of alien herbs, vines and trees that compete and suppress native tree regeneration (Lee, 1974; Craig, 1993). Although similar neighboring islands such as Rota and Tinian also have many of these same factors at work, native pollinators, seed dispersers, and insect predators are still abundant, and the magnitude of recent human disturbance has been quite different on each of these islands. The vegetation on Tinian, for example, was completely devastated during World War II, but Rota was the least disturbed of the inhabited Mariana Islands. Although the vegetation on Tinian has been mostly replaced by nonnative tangantangan (Leucaena leucocephala), one endangered bird, the Tinian Monarch (Monarcha takatsukasae), has increased in recent decades (Lusk et al., 2000). Rota, on the other hand, retains native forests with a high degree of ecological integrity, and apparently has few problems with regeneration in native tree species; however, some bird species such as the Rota Bridled White-eye (Z. c. rotensis) have declined (Fancy and Snetsinger, 2001). The ecological services provided by the native fauna also differ between islands. Although Guam has very few remaining Mariana Fruit Bats (Pteropus mariannus), Rota has a readily noticeable population. At least one native plant species may be obligately bat-pollinated-fianiti or Freycinetia reinecki (Pandanaceae), a vine that bears important fruit for the Mariana Crow.

\section{Field Observations}

We pursued some simple field investigations in Area 50 to test the feasibility and value of various vegetation monitoring techniques. We were interested in replicating previously published studies to evaluate longitudinal comparisons as a tool for monitoring vegetation change. We attempted to replicate the field methods employed by Morton et al. (2000) at Area 50 by surveying a test plot. We relocated one of the original 30 plot centers marked with iron rebar in the ground. We divided the plot into quarters along transect $\mathrm{K}$ and surveyed a single quarter with a radius of $9.77 \mathrm{~m}$. We counted 22 stems of 5 species with diameter at breast height (DBH) $>24 \mathrm{~mm}$. We also surveyed stems $<24 \mathrm{~mm}$ DBH in a 1 x $1 \mathrm{~m}$ subplot. We recorded 27 stems of 8 species. Surveying 
the subplot took $<10$ minutes to complete, but the $75 \mathrm{~m}^{2}$ quarter plot of larger stems required $>40$ minutes. We estimated it would require approximately 2 hours and 50 minutes to complete each of the $300 \mathrm{~m}^{2}$ plots, therefore, we estimate that it will require 85 work hours for 2 people to complete 30 vegetation plots once plot centers have been located. Given the difficultly of locating old plot markers in Area 50, at least 2 full work weeks probably will be required to complete another basic vegetation survey of the site. Simply finding plot centers, however, may be quite time consuming or even impossible in some cases. Furthermore, 5 other plant species with DBH $<24 \mathrm{~mm}$ that were in the test plot we surveyed did not meet criteria for data recording and were therefore effectively ignored by the technique. We concluded that this technique alone would be unsatisfactory for addressing key questions regarding the regeneration of young forest trees in response to any experimental management actions in Area 50, but may be useful in conjunction with other techniques.

We also made a preliminary investigation of Elaeocarpus joga reproduction in Area 50 by measuring and permanently tagging all seedlings we could find. We observed 51 seedlings with an average height of $14.5 \mathrm{~cm}( \pm 0.95 \mathrm{SE})$ under the canopies of 3 mature trees. None of the seedlings were $>32 \mathrm{~cm}$ in height. From this very limited data, the frequency of seedlings in size classes $>$ $12.5 \mathrm{~cm}$ appeared to decline markedly in abundance (Fig. 5). Although this effort did not represent an exhaustive search, we observed no other sapling or intermediate sized E. joga trees in Area 50 or the vicinity, whereas we observed several larger saplings and small trees during a short visit to the Sabana region of the Island of Rota, some of which were growing up through a dense ground cover of grasses.

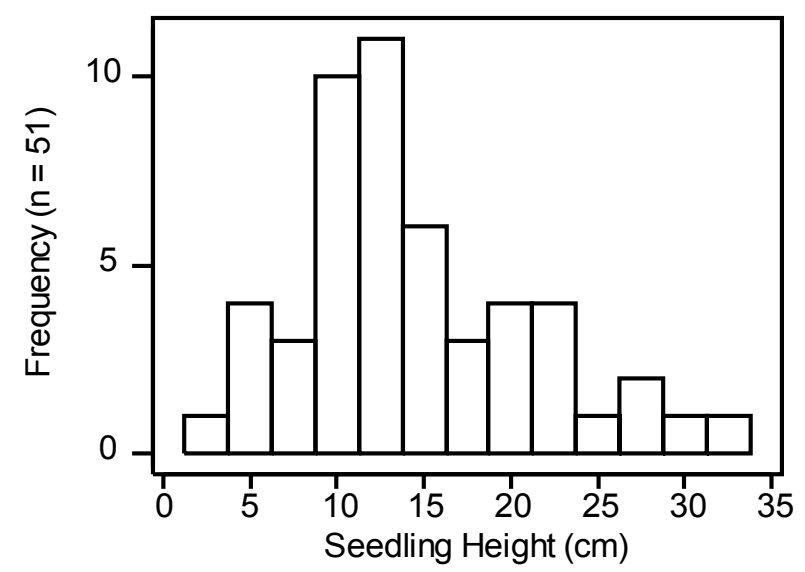

Figure 5. Height distribution of 51 Elaeocarpus joga seedlings found under 3 mature tree canopies in Area 50, Andersen Air Force Base, Guam, May 2004.

In 2005, we were able to revisit seedlings under 2 of the 3 joga canopy sites. Only 9 of the 47 joga seedlings tagged at these sites in 2004 were found alive 13 months later. We relocated tags of 22 seedlings that had died or disappeared, but we were unable to relocate 16 other seedlings from 2004. We estimated annual seedling survival to be $0.29( \pm 0.082 \mathrm{SE})$. Average growth of the 9 remaining seedlings was $4.67 \mathrm{~cm}( \pm 1.55 \mathrm{SE})$. Browse damage was observed on leaves of one of the taller $(35 \mathrm{~cm})$ remaining seedlings. Six young seedlings, some still exhibiting cotyledons or 
seed-leaves, were noted underneath one tree canopy. These seedlings had a mean height of $6.2 \mathrm{~cm}$, and represented recruitment at the site since our last visit.

We concluded that there is at least limited reproduction occurring in this species within Area 50, but seedlings may be browsed, trampled, or uprooted by mammals at early stages of development. The seeds of joga, which may have once been dispersed by large frugivorous birds, such as the Mariana Fruit-Dove, continue to fall and germinate at least as far as the canopy of mature trees and may still be consumed and passed by the smaller Philippine Turtle-Dove (Streptopelia bitorquata). The seedlings we marked may be monitored during subsequent visits to determine survival and growth rates, but larger samples of this and other species will be necessary to address vegetation change and regeneration issues. Small exclosure fences and rat-proof cages may also be useful to determine factors limiting regeneration in limestone forest tree species. Nested exclosures consisting of rat-proof cages within fences could be used to isolate the effects of rodents from other larger mammals, presuming some large mammals may continue to inhabit the larger enclosure around Area 50.

\section{Cycad Aulacaspis Scale}

We also observed the rapid colonization of a new plant pathogen between our visits to Guam in 2004 and 2005. In the course of one year, cycad aulacaspis scale (CAS) - Aulacaspis yasumatsui Takagi (Hemiptera: Diaspididae) has become established and affected almost every cycad (Cycas circinalis) plant we observed on Guam. Only a few plants in deep shade seemed unharmed. This white scale covered many of the green cycad leaves, causing them to turn brown. Many cycads have produced new foliage, not all of which was covered by CAS. While not quantified, the effect of this pathogen was noticeable over large parts of the Northern Guam landscape. Although the pathogen appears to be in the process of killing these plants, the long-term effects of CAS are not known. Because they have stores of starch in their bulky trunks, some cycads may survive the loss of leaves caused by the infestation. Cycads are an important part of forest communities and an important food resource for vertebrates on Guam. Their loss could jeopardize the recovery of native fauna such as Mariana Fruit Bats or Mariana Crows. Recent attempts to release Australian ladybird beetles, Rhyzobius lophanthae Blaisdell (Coleoptera: Coccinellidae), may mitigate the widespread mortality. We observed no CAS on the Island of Rota despite its close proximity and frequent exchange of passengers and cargo with Guam. Cycads appeared to be abundant only in a limited area of coastal limestone forest on Rota. Montgomery Botanical Center of Coral Gables, Florida, has been maintaining an internet site with frequently updated information on CAS at http://www.montgomerybotanical.org/.

\section{NPS Units of War in the Pacific National Historical Park (WAPA)}

During our stay in Guam, we visited five of the seven small units of War in the Pacific National Historical Park (fig. 6). Because the Park lacked a comprehensive vascular plant checklist, we made a preliminary list of plants that we saw during our brief forays into the Park units. Altogether, more than 200 plant species were identified, and this list was forwarded to the NPS Inventory and Monitoring program, which sent a botanist to Guam during summer 2004 and 2005 to complete the inventory and collect voucher specimens of plants from WAPA. We consulted with Lynn Raulerson of the University of Guam about the needs of the Herbarium and its capacity to store the WAPA voucher specimens to be made during the summer inventory. We also 


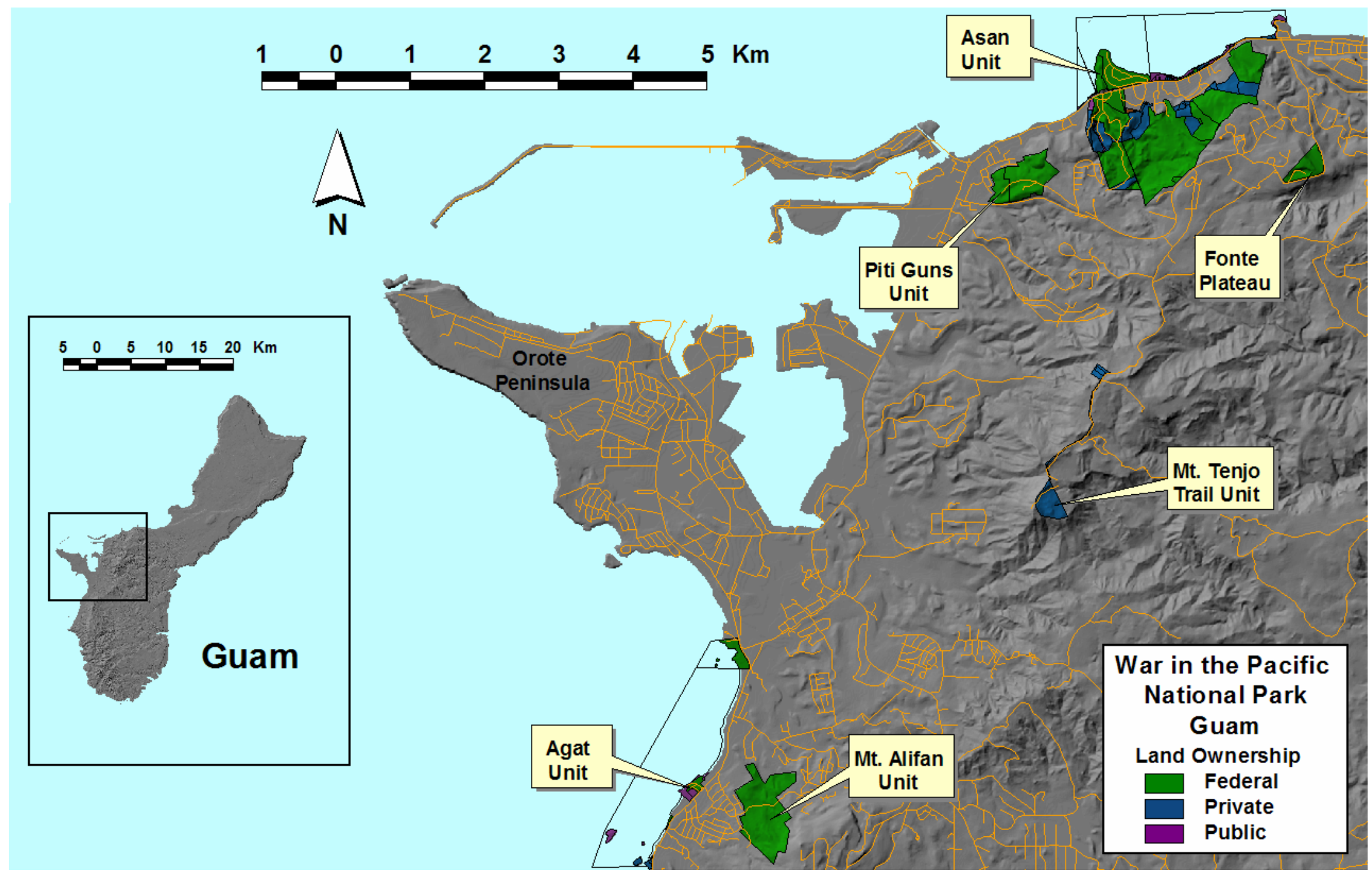

Figure 6. War in the Pacific National Historical Park units and land ownership designations. 
obtained a copy of a survey of terrestrial organisms in WAPA by Raulerson (1979) to provide to the I\&M program in Hawai i.

On our return to Hawaii in 2004, we met with Joan Yoshioka, who was hired to carry out the WAPA vascular plant inventory in June and July, 2004. We shared with her our photographs of the five park units we visited and helped her plan survey routes. We identified some areas of particular interest likely to harbor native vegetation, and suggested that these be priorities for survey. Using NPS aerial photographs, we helped Joan create a time allocation for field surveys to maximize the area covered during the limited number of field days. When Joan returned from Guam, we assisted her with plant identification from digital photographs. Voucher specimens remained in Guam and will be labeled and processed at a future date. Eventually, the specimen collection data will be entered into a NPS database (NPSpecies). Yoshioka (2005) documented $>400$ vascular plant species within the seven park units.

\section{Description of Vegetation in WAPA Units}

Two of the WAPA units are coastal-(1) Agat Beach at Gaan Point and (2) Asan Beach. Most of the area within these two units is disturbed, but both have some native strand and coastal limestone vegetation. Agat Beach at Gaan Point supported native strand of indigenous grasses, vines, and a narrow coastal forest of sea hibiscus (Hibiscus tiliaceus) and rosewood (Thespesia populnea). Several offshore islets are within the Park boundaries; these were not visited, but appeared to support native xerophytic scrub vegetation. The Agat unit extends both north and south from Gaan Point, but the entire stretch of beach was not surveyed during our brief visit. The Asan Beach unit has a limestone ridge on its southern boundary that retains elements of native limestone vegetation, including a rare moonseed vine considered a species of concern on Guam (Tinospora homosepala). Asan Beach stretches north from this limestone ridge to the base of a rocky cliff that supports native coastal shrubs. This unit is contiguous with a larger area stretching upslope to an overlook (Asan inland or upland unit). The Asan upland unit contains at least two stream drainages and has both ravine forest and disturbed savanna vegetation. There is native limestone forest on a ridge at the southern boundary and on a rocky slope at the park's northern boundary.

The Mt. Tenjo unit is essentially a corridor trail between Mt. Chaochao and Mt. Tenjo, with some additional area around Mt. Tenjo. Although much disturbed by off road vehicles along the trail (formerly an unpaved road), we recorded a number of native shrub and fern species characteristic of savanna vegetation in this unit. Although this unit had areas of bare soil eroded by fire and mechanical disturbance, its vegetation had the highest percentage of native plant species of any surveyed during our visit. We found 15 native-shrub species, 10 native ferns, 7 indigenous sedges, and 5 native grasses growing along the trail corridor. The endemic grass Dimeria chloridiformis was not uncommon in the area; this species may be a candidate for future restoration efforts in eroded areas.

The Piti Guns unit was examined along a trail for visitors to a WWII gun emplacement overlooking Apra Harbor. A number of ornamental trees were found here in the vicinity of a Honduran mahogany (Swietenia macrophylla) plantation. A few native tree and herb species were also noted in the unit. On our return, we found that the actual NPS lands are much more extensive in this unit than was indicated on the map, so there was a large part of the unit that we did not survey. We did not identify plants in two other WAPA units for lack of time. Fonte Plateau included a WWII bunker and part of an old quarry. We did not investigate this unit, but it appeared to be highly disturbed and covered by secondary vegetation. Joan Yoshioka (2005) found native vegetation on a steep ridge between the old quarry and the highway. Clearly, even 
areas much disturbed by past land use are capable of supporting native trees and shrubs on inaccessible slopes and ridges. A seventh WAPA parcel upslope of Agat Beach, the Mt. Alifan unit, was not investigated by us, but was found by Yoshioka (2005) to contain limestone forest, savanna vegetation, and ravine forest along streams. On a previous visit to the peak of Mt. Alifan in the Naval Magazine, native trees, such as joga, coral tree (Erythrina variegata), and Merrilliodendron megacarpum, a Guam rarity, were observed on slopes in or just above the Park unit.

Potential research questions in the larger two units include issues of erosion and sedimentation on the reefs of Agat and Asan Bays. The larger units were also found to have areas with relatively native limestone forest, thus questions involving alien plant and ungulate impacts on native vegetation are appropriate to the park. Determination of the stand structure and reproduction of native tree species will help define management strategies in WAPA, and may also be important to other conservation areas on Guam (e.g., Ritidian Point NWR and overlay refuges). Research on restoration techniques in limestone forest and other natural vegetation types may also be relevant to the Park Service mission in Guam.

\section{Rota}

The island of Rota was spared much ecological destruction during WWII in comparison to the islands of Guam, Saipan, and Tinian, having never experienced major military battles (Baker, 1946). With a small human population and limited agriculture, Rota has also been less developed than the other islands. Small in size, only $85 \mathrm{~km}^{2}$, Rota is $496 \mathrm{~m}$ in elevation at its highest point, making it slightly taller with substantially steeper slopes than other islands in the southern part of the archipelago. Rota also has a substantial portion of land in designated conservation areas, although other lands also remain relatively undisturbed (fig. 7).

Consequently, intact limestone forest covers a majority of the island. This forest appears taller in stature than the limestone forest of Guam perhaps due to the sheltering effect of steep slopes as opposed to the broad flat plateau of Northern Guam. Rota also hosts several rare plants, including Tabernaemontana rotensis, and nearly all of the endangered Serianthes nelsonii trees in existence, as well as two endangered species that occur exclusively on Rota-Osmoxylon mariannense (Araliaceae), and Nesogenes rotensis (Verbenaceae).

Rota has experienced no recent avifaunal extinctions, although the Micronesian Megapode and Mariana Swiftlet are notably absent as a likely result of early human colonization (Steadman, 1992). Some species, however, such as the Rota Bridled White-eye and Mariana Crow have been in decline for largely unknown reasons (Craig and Taisacan, 1994; Fancy and Snetsinger, 2001; U.S. Fish and Wildlife Service, 2002). A unique population of insectivorous Sheath-tailed Bats (Emballonura semicaudata) also occurred on Rota, but is apparently extirpated, possibly due to disturbance of their cave habitats and heavy insecticide use (Lemke, 1987). Mariana Fruit Bats, however, were visibly abundant from the Taisacan property near Uyulan Hulo.

Most of the ecological services provided by the native vertebrates, such as insectivory, pollination, and seed dispersal, still appear to function on Rota. In addition, however, introduced Philippine sambar deer are responsible for unnatural native plant herbivory, and rats (Rattus spp.) are likely seed predators, as well as nest predators of native birds. The abundant Black Drongo (Dicrurus macrocercus) may also be responsible for nest predation of native forest birds. Despite these depredations and frequent typhoons, limestone forest regeneration processes appear to be unimpeded in comparison to Guam, with the exception of lack of reproduction in some endangered plants. For example, seeds of Serianthes nelsonii may be depredated by 
arthropods before reaching maturity, and Osmoxylon mariannense may be subject to bark stripping by deer before reaching reproductive age. Abundant birds that disperse large seeds include the Mariana Fruit Dove and the White-throated Ground Dove, whereas the Cardinal Honeyeater (Myzomela rubratra) may serve as an important pollinating bird. Endangered species such as the Mariana Fruit Bat and Mariana Crow may have once figured prominently in seed dispersal, especially where nests or roosts resulted in patchy deposition of numerous seeds.

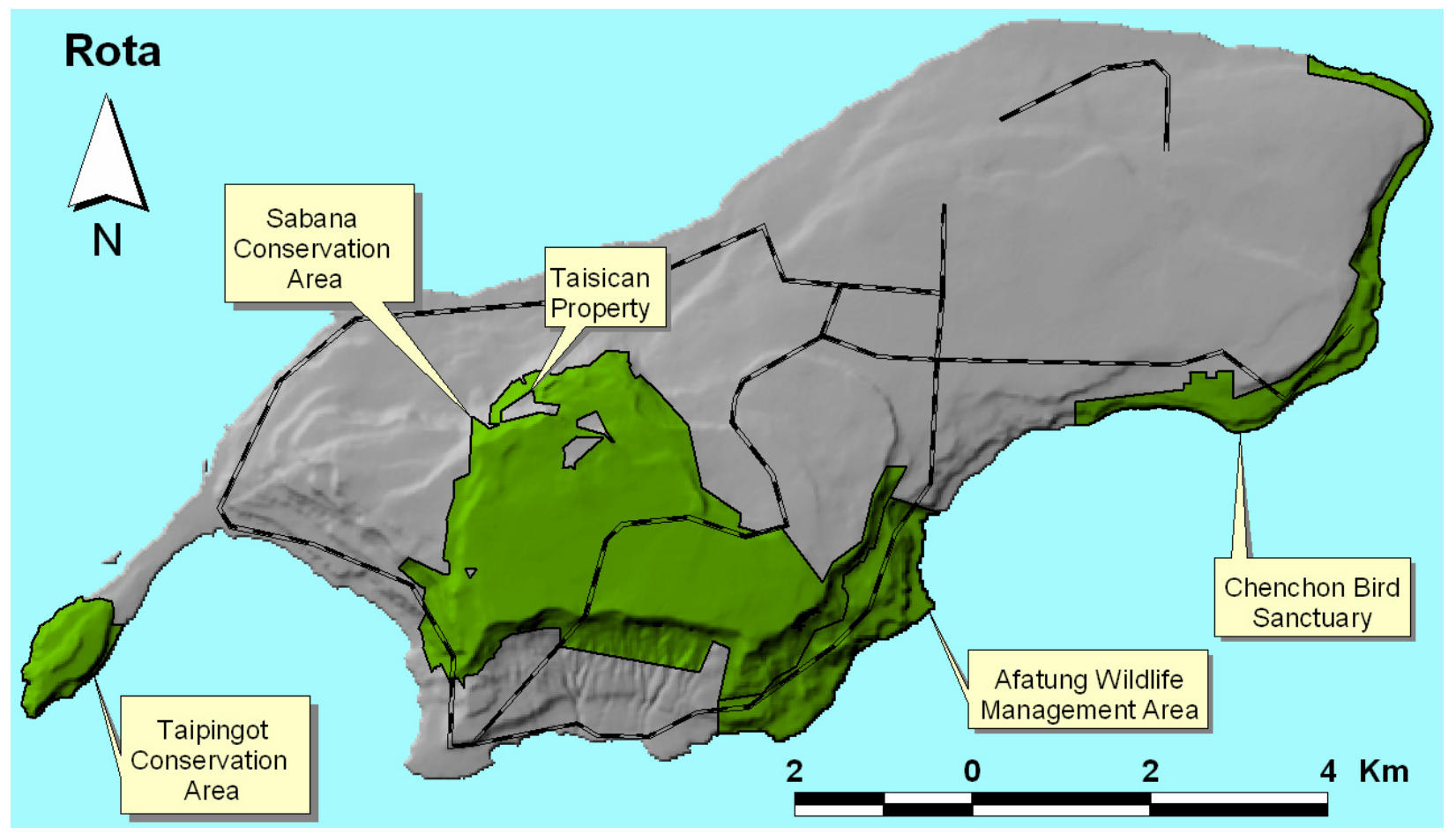

Figure 7. Approximate boundaries of conservation lands on the island of Rota, Commonwealth of the Northern Mariana Islands.

\section{Saipan}

Saipan was the site of major agricultural development during the period of Japanese government, then the site of one of the largest military invasions and occupations during WWII. Saipan is now densely settled and developed with major economies in international tourism, textiles, and small scale agriculture. Mueller-Dombois and Fosberg (1998) stated that the entire island has been "profoundly disturbed" and vegetation patterns are therefore, "neither simple nor stable." The topography of Saipan is more complex than the lower island of Tinian, but not as steep as Rota. Nonetheless, Saipan still contains most native birds including the island endemic Golden White-eye (Cleptornis marchez), and three endangered species - the Nightingale Reedwarbler, the cave-dwelling Mariana Swiftlet, and the anomalously distributed Micronesian Megapode. These species occur within the various conservation areas as well as some unprotected lands on the Northern part of the island (fig. 8). 


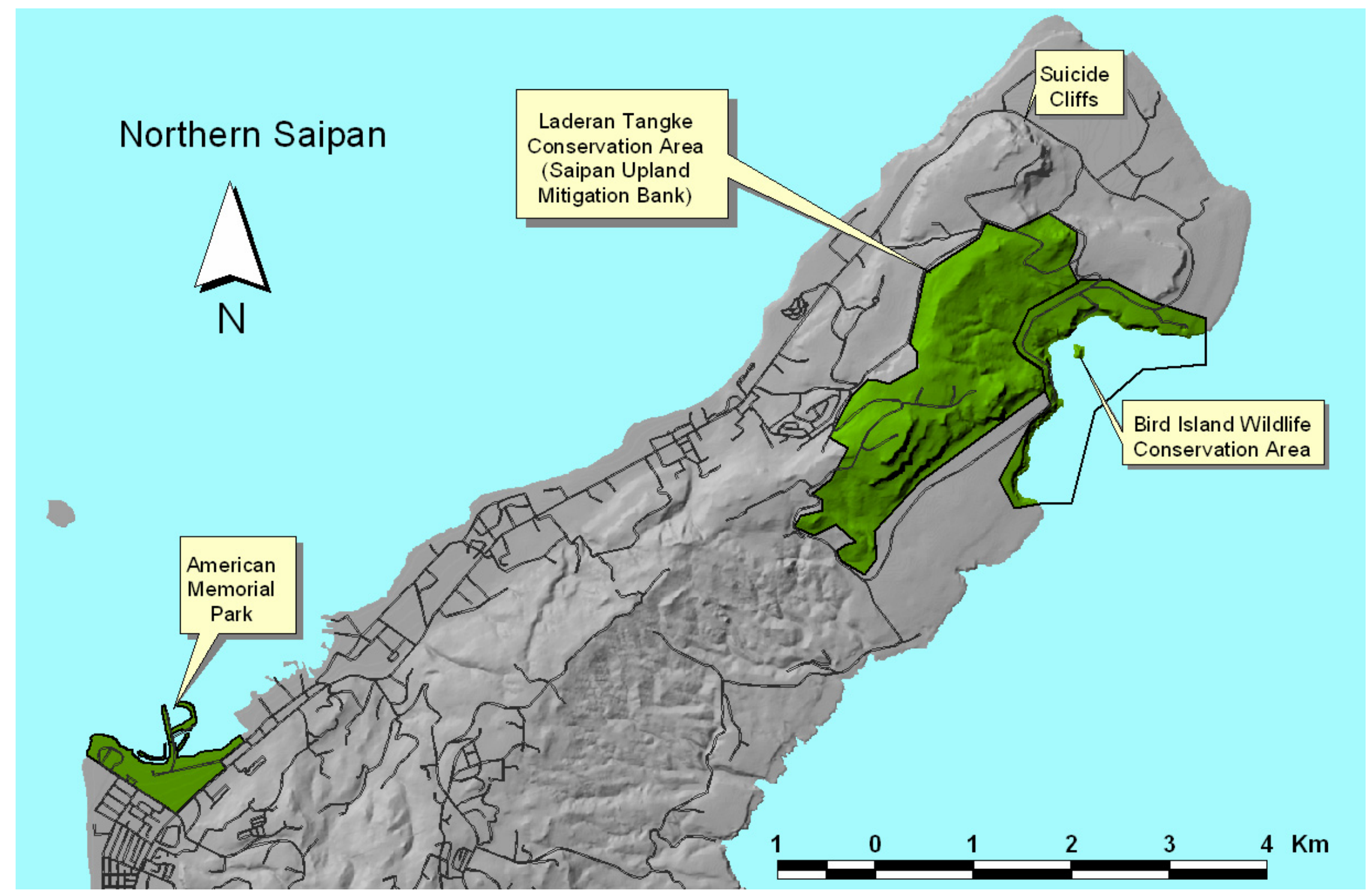

Figure 8. Approximate boundaries of conservation lands, natural areas, and U.S. National Parks of Northern Saipan, Commonwealth of the Northern Mariana Islands. 


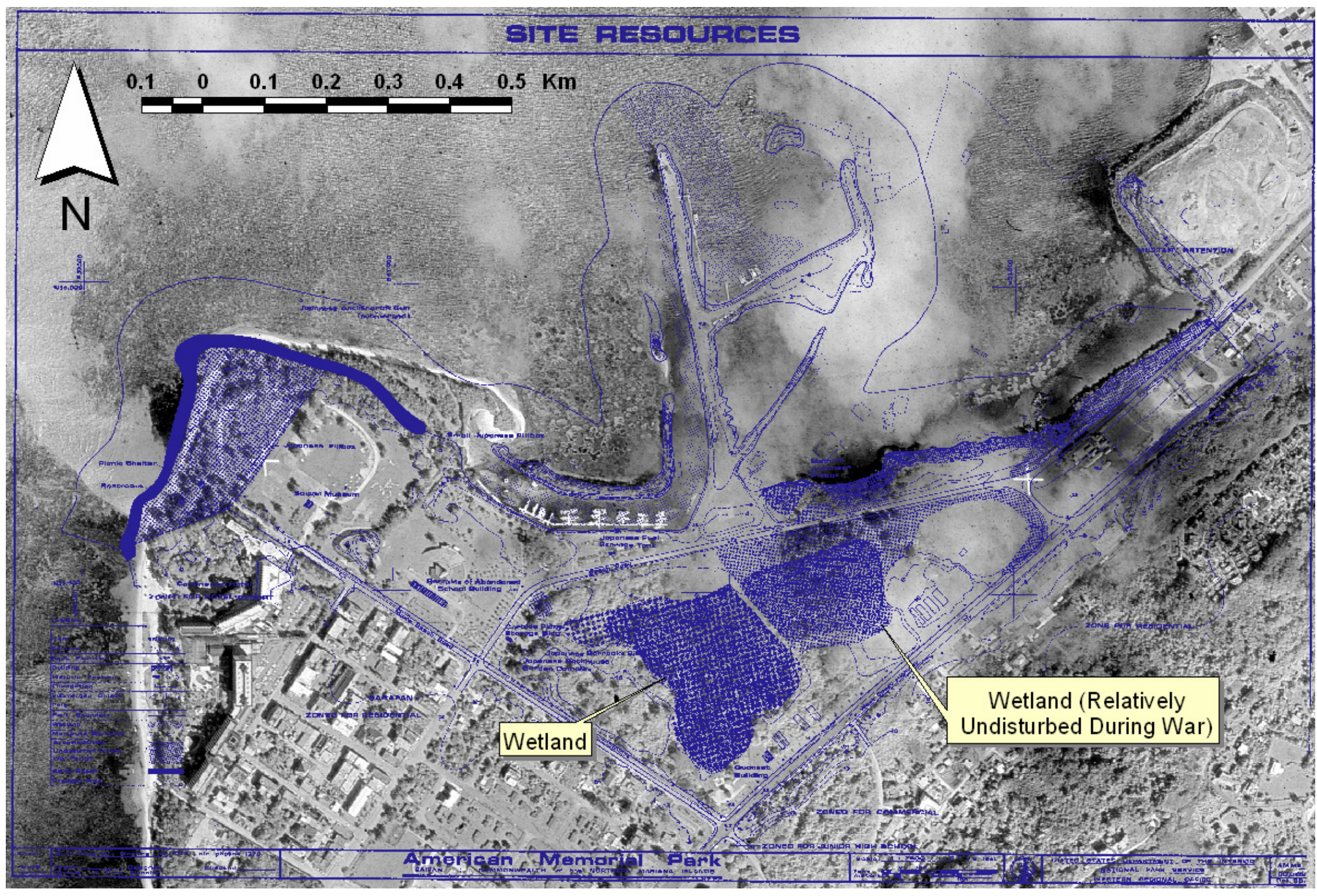

Figure 9. Digital Orthographic Photo imagery and American Memorial Park, Saipan, showing location of wetlands. 
Another anomalous feature of Saipan is the presence of mangroves (Bruguiera gymnorrhiza; Rhizophoraceae), unusual in the Mariana Islands. Wetlands supporting stands of mangrove are present in coastal estuaries of the Garapan district where muddy freshwater and brackish streams occur. American Memorial Park, a U.S. National Park, contains an isolated small mangrove wetland inhabited by the endangered Marianas Common Moorhens (Gallinula chloropus guami) and Nightingale Reed-warblers (Johnson, 2003). Partulid treesnails (Partula spp.), considered candidate endangered species, are also known from this locality. This wetland was apparently used as a landfill site as late as the 1980s and has been cut off from regular tidal inundation by the construction of a marina and surrounding roads, yet ground water salinity remains high enough to favor mangroves in this area (Raulerson and Rinehart, 1989; fig. 9). Vines and invasive woody vegetation form dense thickets throughout the wetland.

Upland limestone forest, although containing abundant naturalized tree species, such as siris tree (Albizia lebbeck, Fabaceae) and ubiquitous tangantangan, is also rich in native species such as umumu (Pisonia grandis), nunu (Ficus prolixa), and coral tree. Unlike those of Guam, limestone forests on Saipan support a dense understory of gulos (Cynometra ramiflora). Due to extensive agricultural clearing, cycads are apparently missing except where they have been replanted.

\section{Research Questions}

We developed several biological questions of interest regarding native limestone forest regeneration on Guam and approaches to investigation. Different ecological conditions between islands of the Marianas, such as the presence and absence of ecological services from the native fauna, similarities and differences in native and alien forest tree species present, and different densities in mammalian herbivores and seed predators lend themselves to natural experiments. Furthermore, experimental manipulations may easily be imposed to further control some ecological effects, particularly those of alien mammals. Finally, alien species control may have unintended consequences, such as the proliferation rats after the control of BTS and alien vine proliferation after the removal of ungulates on the island of Sarigan (Kessler, 2002). These issues are also amenable to experimental manipulation and comparison between islands.

Although Guam may lack the ecological services of pollination and seed dispersal, and the effects of herbivorous mammals may be pronounced, seed predation by rodents may be low due to abundant BTS. These ecological factors may also interact with changing external factors such as typhoons, possibly increasing in frequency and intensity and causing changes in structural disturbance regimes that favor some alien plant species. Abundant invasive plant species may in turn alter competitive interactions and ecosystem properties such as nutrient cycling on Guam. In comparison, an island that has a relatively full complement of native fauna such as Rota, also has more intensively harvested herbivorous mammals, relatively intact surface substrates, but higher rodent abundance. Comparison of forest regeneration processes between these islands may lead to prioritization of limiting factors and allow the development of science-based restoration end-states for the Mariana Islands. Questions which can be addressed by a comparative study between Area 50 on Guam, and Rota include:

- Is reproduction and regeneration in limestone forest species Elaeopcarpus joga, Artocarpus marianensis, and Pisonia grandis on Guam limited in comparison to Rota? 
- If so, what are the limiting factors?

$\circ$ Herbivory/Seed Predation
$\circ$ Pigs
$\circ$ Deer
$\circ$ Rats
$\circ$ Insects
$\circ$ Invasive vines

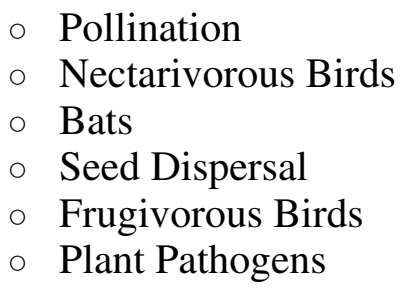

- If alien vines are a substantial limiting factor for native trees, is understory digging by pigs causing these vines to proliferate?

- Will the removal or reduction of large herbivores cause even greater proliferation of alien vines (e. g., Kessler, 2002)?

- Will the frequency, cover, and abundance of alien vines ultimately decrease in the absence of alien ungulates?

- Will selected native tree species recruit more seedlings in areas where alien vines are mechanically removed?

We propose the following strategies to study these questions: vegetation plots to determine the presence and age structure of intermediate-sized saplings and young native trees at large; experiments to sequentially control the effects of seed predation and herbivory by rodents and other mammals within nested exclosures; frequency, cover, and abundance measurements of alien plants, particularly dense vine cover, inside and outside ungulate exclosures on both disturbed and undisturbed substrates; removal of dense vine cover within exclosures to determine the effects of these plants on the regeneration of native trees; and longitudinal studies of tagged seedlings to determine survival and growth at different life stages.

Results from these proposed field studies will allow us to determine the relative magnitude of impacts from herbivores and seed predators, the loss of seed dispersers, suppression of regeneration by alien plants, and the lasting impacts of substrate modification on both native and alien plant regeneration. Prioritizing these impacts will help to determine management efforts that will have the greatest effect towards recovering native biotic communities and in developing an ecosystem approach to alien species management in the Mariana Islands. Given the similarities of limestone forests on Guam and the island of Rota, Saipan, and Tinian, where little native forest remains, findings from these studies may have broad application for managing alien species in these other locations, as well as in more distant islands subject to similar current or potential biological invasions.

\section{Acknowledgments.}

Sponsoring our work were the following U.S. Geological Survey (USGS) units-Wildlife and Terrestrial Resources, Terrestrial, Freshwater and Marine Ecosystems, and Pacific Island Ecosystems Research Center. We gratefully acknowledge the assistance, facilitation, and guidance of many people, but particularly E. Campbell III (U.S. Fish and Wildlife Service), C. Kessler (U.S. Fish and Wildlife Service), and L. Raulerson (University of Guam). Thanks to A. Brooke and D. Minton for helpful comments on a previous draft of this report. Any use of trade, product, or firm 
names in this publication is for descriptive purposes only and does not imply endorsement by the U.S. Government. All photographs by Linda Pratt and Steven Hess, USGS.

\section{References Cited}

Athens, J.S., and Ward, J.V., 2004, Holocene vegetation, savanna origins and human settlement on Guam: Records of the Australian Museum, supplement 29, p. 15-30.

Baker, R.H., 1946, Some effects of the war on the wildlife of Micronesia: Transactions of the North American Wildlife Conference, v. 11, p. 207-213.

Baker, R.H., 1951, The avifauna of Micronesia, its origin, evolution, and distribution: University of Kansas Publications, Museum of Natural History, v. 11, p. 205-213.

Craig, R.J., 1992, Ecological characteristics of a native limestone forest on Saipan, Mariana Islands: Micronesica, v. 25, p. 85-97.

Craig, R.J. 1993, Regeneration of native Mariana Island forest in disturbed habitats: Micronesica, 26:99-108.

Craig, R.J., and Taisacan., E., 1994, Notes on the ecology and population decline of the Rota Bridled White-eye: Wilson Bulletin, v. 106, p. 165-168.

Falanruw, M.C., Cole, T.G., and Ambacher, A.H. 1989, Vegetation survey of Rota, Tinian, and Saipan, Commonwealth of the Northern Mariana Islands: Resource Bulletin PSW-27, Berkeley, California: U.S. Department of Agriculture, Forest Service, Pacific Southwest Research Station.

Fancy, S.G., and Snetsinger, T. J., 2001, What caused the decline of the Bridled White-eye on Rota, Mariana Islands?: Studies in Avian Biology, v. 22, p. 274-280.

Fosberg, F.R., 1960, The vegetation of Micronesia: Bulletin of the American Museum of Natural History, v. 119, p. 1-75.

Johnson, N.C., 2003, An assessment of the nightingale reed-warbler (Acrocephalus luscinia) population in American Memorial Park on Saipan, Northern Mariana Islands: Marianas Conservation Unlimited, Final Report.

Kessler, C.C., 2002, Eradication of feral goats and pigs and consequences for other biota on Sarigan, Commonwealth of the Northern Mariana Islands. Pp.132-140 in Veitch C.R., and Clout, M. N., Eds., Turning the tide: the eradication of invasive species: IUCN SSC Invasive Species Specialist Group, IUCN, Gland, Switzerland and Cambridge, UK.

Lee, M.A.B., 1974, Distribution of native and invader plant species on the island of Guam: Biotropica, v. 6, p. 158-164.

Lemke, T.O., 1987, Sheath-tailed Bats rediscovered in the Mariana Islands: Bats, v. 5, p. 1-7.

Lusk, M., Hess, S., Reynolds, M., and Johnston S., 2000, Population status of the Tinian Monarch (Monarcha takatsukasae) on Tinian, Commonwealth of the Northern Mariana Islands: Micronesica, v. 32, p. 181-190.

Morton, J.M., Amidon, F.A., and Quinata, L.R., 1998, Baseline surveys of vegetation in Area 50, Andersen Air Force Base, Guam: Prepared by U.S. Fish and Wildlife Service, Pacific Islands EcoRegion, Dededo, Guam and I Tano' Consulting, Agana, Guam.

Morton, J.M., Amidon, F.A., and Quinata, L.R., 2000, Structure of a limestone forest on Northern Guam: Micronesica, v. 32, p. 229-244.

Mueller-Dombois, D., and Fosberg, F.R., 1998, Vegetation of the tropical Pacific Islands: Springer. New York, New York, USA.

Perlman, S., and Wood K., 1994, Survey report of the seacliffs of Andersen Air Force Base Guam: Unpublished report prepared by National Tropical Botanical Garden, Lawai, Hawaii. 
Perry, G., Campbell, E.W. III, Rodda, G.H., and Fritts ,T.H., 1999, Managing island biotas: brown treesnake control using barrier technology: Proceedings of the Vertebrate Pest Conference, v. 18, p. 138-143.

Perry, G., and Morton, J.M., 1999, Regeneration rates of the woody vegetation of Guam's Northwest Field following major disturbance: land use patterns, feral ungulates, and cascading effects of the brown treesnake: Micronesica, v. 32, p. 125-142.

Quinata, L., 1994, Vegetation baseline survey, Andersen Air Force Base, Guam. Report on file with U.S. Fish \& Wildlife Service, Honolulu, Hawaii.

Raulerson, L. and Rinehart, A., 1989, Vegetation of American Memorial Park, Saipan, Mariana Islands: Cooperative Park Studies Unit Technical Report 70, University of Hawaii at Manoa. Honolulu, Hawaii.

Raulerson, L. and Rinehart, A., 1991, Trees and shrubs of the Northern Mariana Islands: Coastal Resources Management, Saipan, Commonwealth of the Northern Mariana Islands.

Raulerson, L. and Rinehart, A., 1992, Ferns and orchids of the Northern Mariana Islands: Raulerson and Rinehart, Agana, Guam.

Raulerson, L. 1979, Terrestrial and Freshwater Organisms within and Limnology and Hydrology of the Guam Seashore Study Area and the War in the Pacific National Historical Park: University of Guam, Department of Biology.

Ritter, M.W., and Naugle, C.M., 1999, Population characteristics, germination and proposed management of Elaeocarpus joga Merr. on Guam: a regionally endemic tree: Micronesica, v. 31, p. 275-281.

Savidge, J.A., 1987, Extinction of an island forest avifauna by an introduced snake: Ecology v. 68, p. 660-668.

Schreiner, I. H., 1997, Demography and recruitment of selected trees in the limestone forest of Guam in relation to introduced ungulates: Micronesica v. 30, p. 169-181.

Steadman, D.W., 1992, Extinct and extirpated birds from Rota, Mariana Islands: Micronesica v. 25, p. 71-84.

Steadman, D.W., 1999, The prehistory of vertebrates, especially birds, on Tinian, Aguiguan, and Rota, Northern Mariana Islands: Micronesica v. 31, p. 319-345.

Stone, B.C., 1970, The flora of Guam: Micronesica v. 6, p. 1-629.

U.S. Fish and Wildlife Service, 1994, Recovery plan for Serianthes nelsonii. Portland, Oregon.

U.S. Fish and Wildlife Service, 1995, Integrated natural resources management plan for Andersen Air Force Base, Guam, Mariana Islands: Department of the Air Force, 36th Air Base Wing, Guam.

U.S. Fish and Wildlife Service, 2002, Draft Revised Recovery Plan for the Mariana Crow, Corvus kubaryi. Portland, Oregon.

Wiles, G.J., Schreiner, I.H., Nafus, D., Jurgensen, L.K., and Manglona, J.C., 1996, The status, biology, and conservation of Serianthes nelsonii (Fabaceae), an endangered Micronesian tree: Biological Conservation, v. 76, p. 229-239.

Yoshioka, J.M., 2005, Vegetation of the War in the Pacific National Historical Park, Guam, Marianas Islands: Pacific Islands Network, USDI National Park Service, Hawaii Volcanoes National Park, Hawaii. 


\section{Appendix I. Travel Itinerary for Guam and Area 50 Site Visit, 2004}

\section{Monday, May 10- Guam National Wildlife Refuge}

We met with Curt Kessler who gave us a presentation on his work to eradicate goats and pigs from Sarigan and Anatahan in the Northern CNMI. Discussed the problem of Operculina ventricosa vines that became abundant after animals were reduced. Curt said that these vines were rare before animal reductions and he had no indication that animal control would cause them to become abundant. We told Curt that we were looking for plots that John Morton and Fred Amidon had installed to examine vegetation in Area 50, marked by rebar with an aluminum can on top. Curt said he had seen some in the past. We then visited area 50 with Curt following recently cut transects. It became apparent that finding any existing plot markers left by Morton and Amidon would be more difficult that we thought and that transect cutting may alter vegetation in the old plots. Dense scrubby vegetation and vines throughout most of Area 50. We went to Ritidian Point lookout on the return to refuge headquarters. Curt requested access for us to Area 50 from Dana Lujan. Toured GNWR facilities - thoroughly reconditioned spacious Navy listening post with new water system, solar panels, and generator power (off power grid).

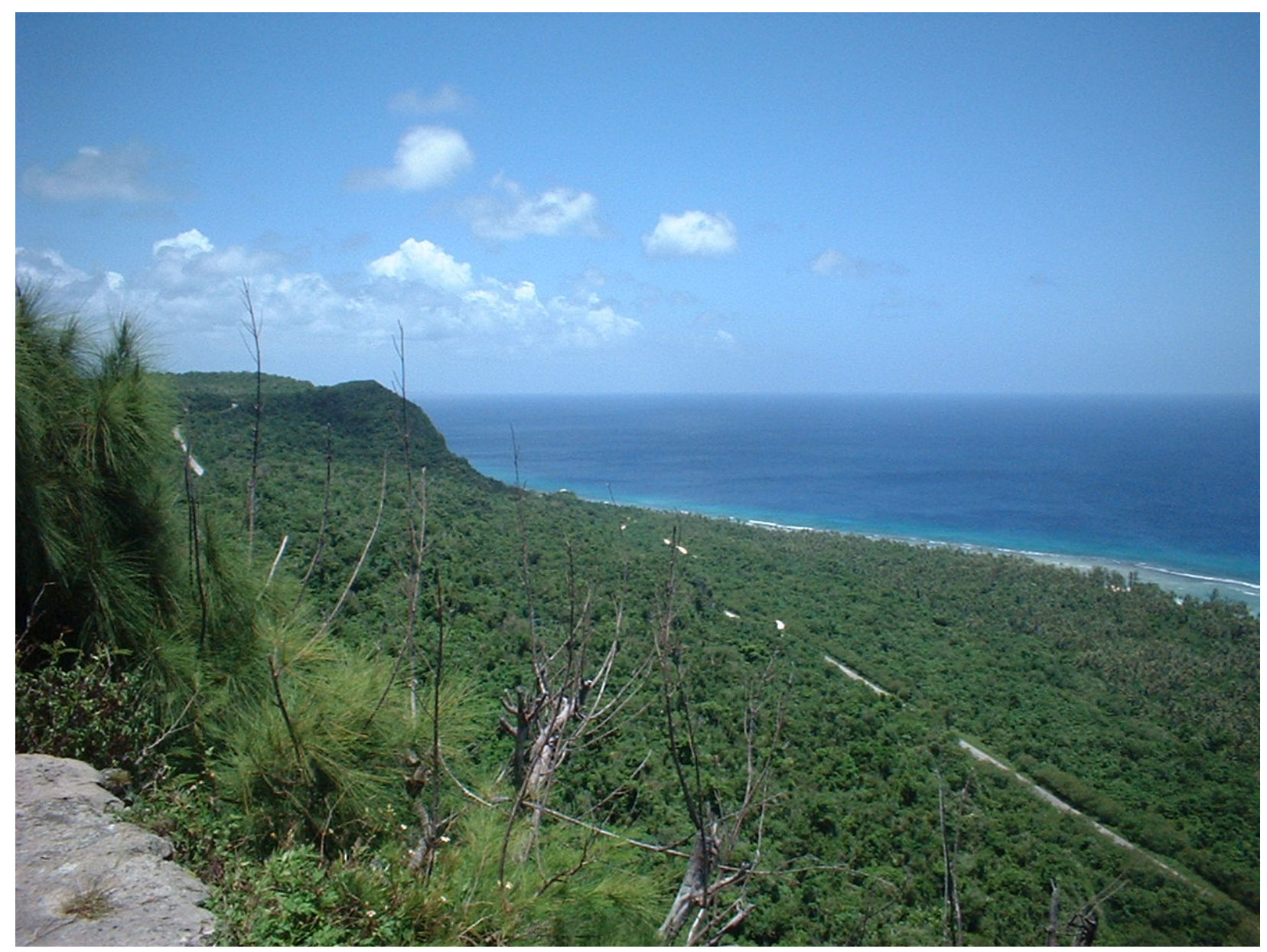

Ritidian Point. 


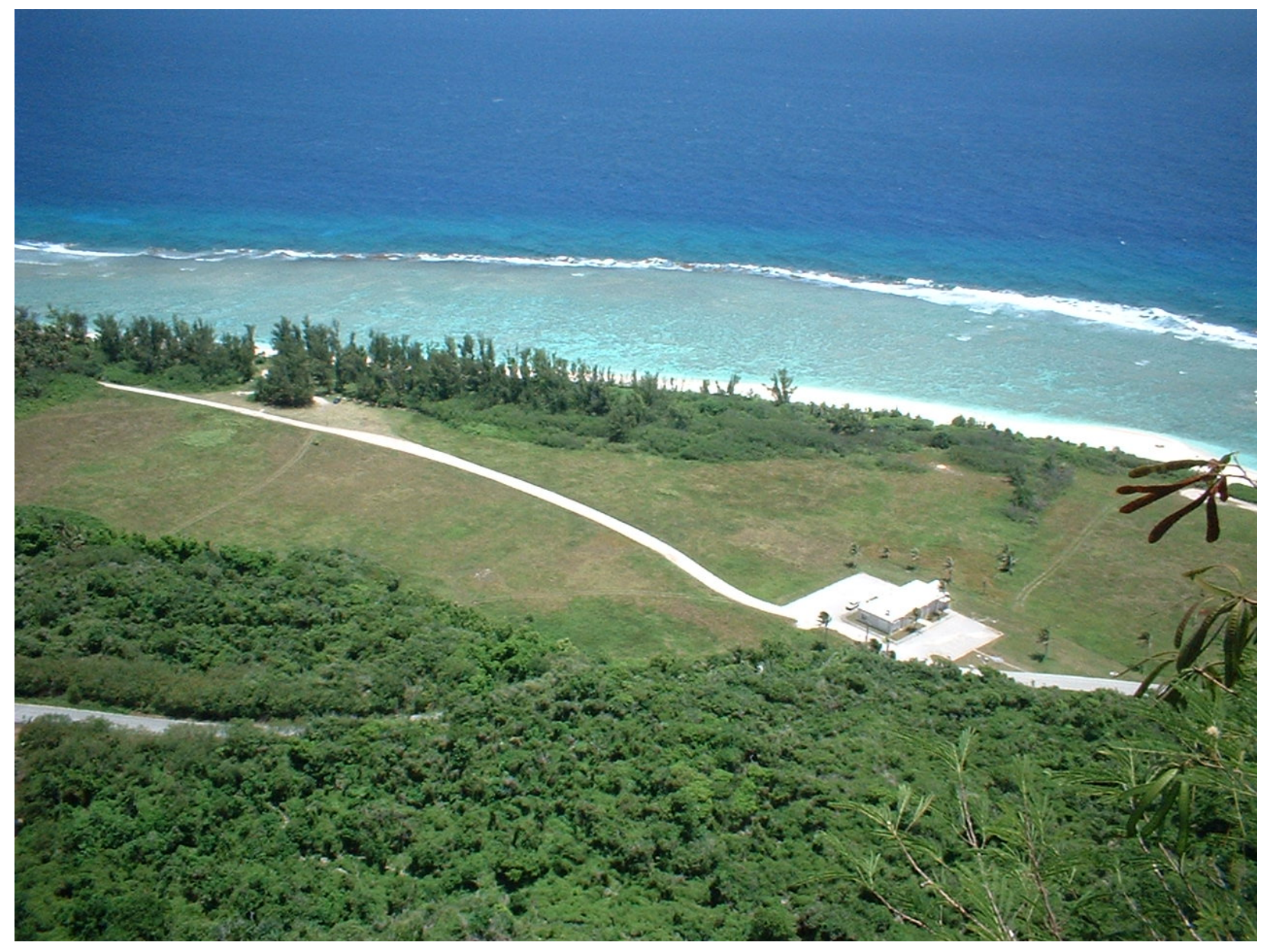

Guam National Wildlife Refuge Headquarters at Ritidian Point.

Met with Earl Campbell who introduced us to Leilani Tacano, a native Guamanian now at Honolulu FWS reviewing the BTS program, Michelle Christy (post-doc), Claudine Tyrrel, and several graduate students from USGS/Colorado State working on a study of a closed population of BTS. Visited snake enclosure (with a double-sided barrier) for closed-population study of BTS. Snakes inside will be pitt tagged and some radio tagged. Anne said she could not secure access to Naval Magazine for us because someone in charge was on leave.

Visited lone Serianthes nelsonii tree enclosed by small wire fence at Ritidian Point. Observed at least 3 seedlings. Discussed lack of management of this tree with Anne Brooke. Tree was flowering and bearing seed pods, but no active propagation has been done (except on Rota). 


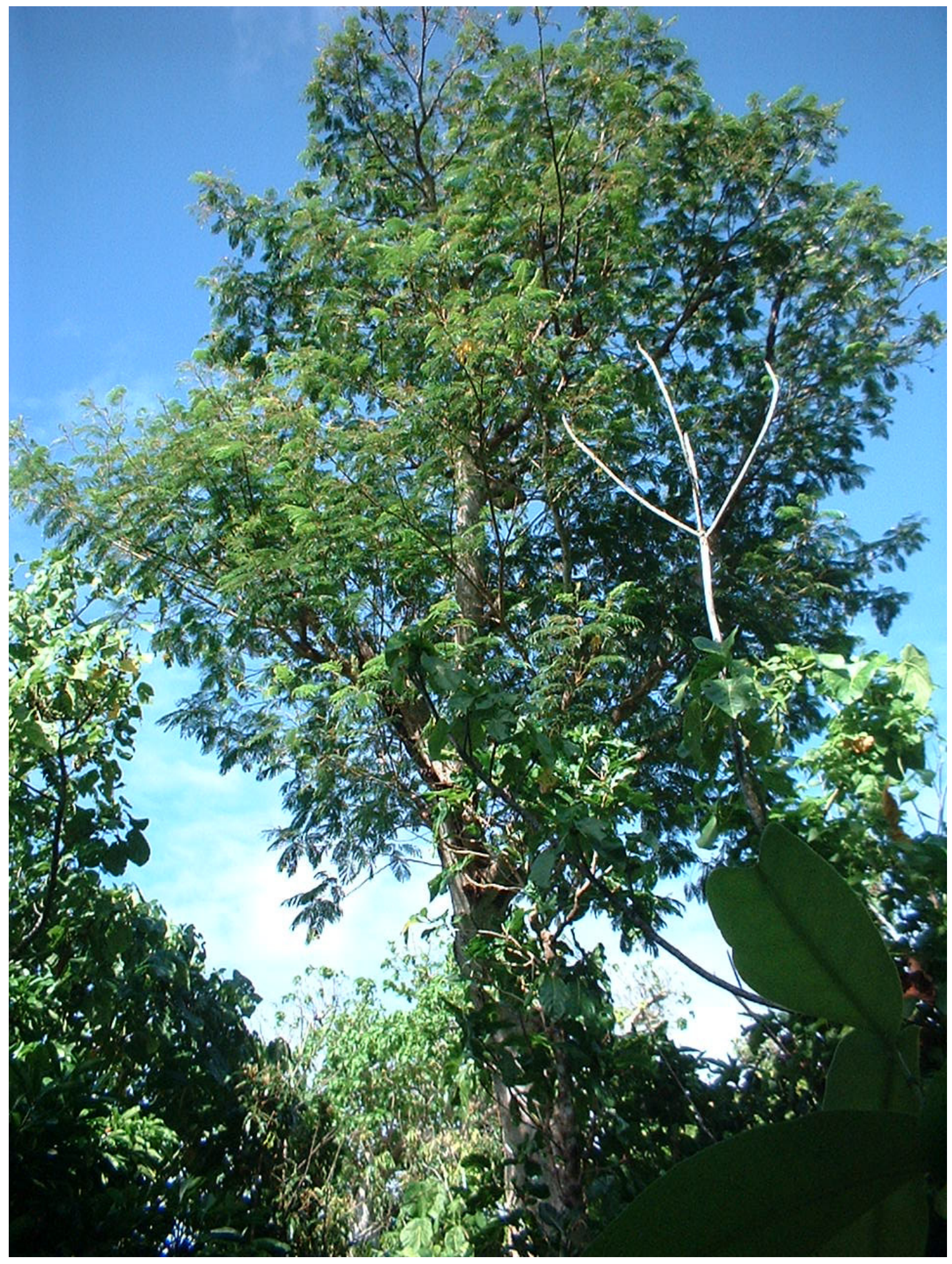

The last Serianthes nelsonii tree on Guam at Ritidian Point. 


\section{Tuesday, May 11- GDAWR Meeting}

About 20 people from various agencies attended our Meeting at GDAWR. Gerry Davis (head of GDAWR) started introductions and turned it over to us. Attendees included Dan Vice, USDA; Diane Vice, Tino Aguon,, from GDAWR; Gerry Deutscher, refuge manager at GNWR; Anne Brooke, refuge biologist for GNWR and Naval Magazine; Claudine Tyrell, Michelle Christy, and their statistician (Aaron) from USGS/Colorado State; and Earl Campbell and Curt Kessler of USFWS. We indicated our intention to undertake vegetation monitoring and/or restoration research in Area 50. Discussion centered on removal of pigs, deer and, rats and their effects on vegetation recovery. Claudine Tyrrel said it was important to understand the effects of rats on plant regeneration because the removal of BTS could lead to an abundance of rats. Earl Campbell brought out the fact that there was possibly a hybrid species of rat on Guam in addition to black rats. There was also much discussion about restoration goals for Area 50. Timeline for barrier construction is in the next few months. Gerry Deutscher expressed the need to know what species composition should be restored, but Tino Aguon was more interested in a self-sustaining native forest rather than particular composition. There was some discussion about trees and plants that are apparently not reproducing in Area 50, including joga, seeded breadfruit, umumu. Tino said these trees were reproducing on Rota and suggested a comparative study to determine why not on Guam. Anne Brooke said she had been studying several species, but only 2 were not being pollinated on Guam, including the obligately bat-pollinated fianiti or Freycinetia. Tino later told us that he was overcommitted and not anxious to see more research without particular applications, as he felt Area 50 had been "studied to death."

Afterwards, we met with David Limtiaco of Guam Forestry and Soil Resources Division. He gave us a presentation on forestry projects on the islands, mostly to provide some ground cover in 'badlands' and prevent siltation of marine resources. They have been using an exotic tree (Acacia auriculiformis) to restore forest cover to bare areas. He gave us maps of Holdridge life zones and vegetation cover on Guam, as well as a Forest Service report on species composition and biomass estimates from IKONOS imagery. This report, however, did not mention joga once.

Afternoon- visited War in the Pacific National Historical Park units Agat and Asan to inventory plants for NPS. Gaan Point in Agat was small with mostly cultivated grasses. Asan unit was much larger with a limestone forest on a ridge perpendicular to shore. Native tree and shrub species were present, but were scattered in a shrubland dominated by alien tangantangan. 


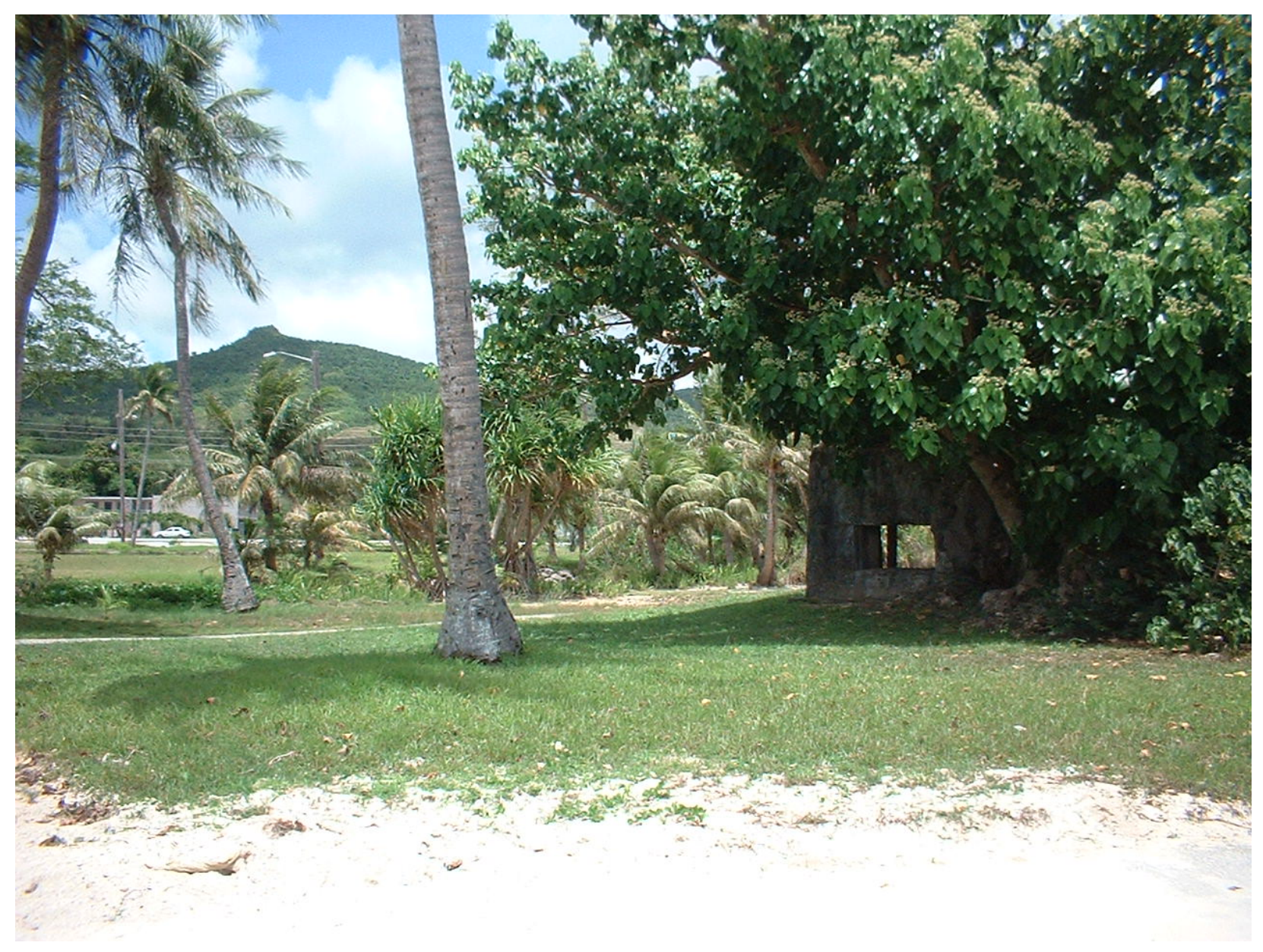

War in the Pacific National Historical Park- Gaan Poin, Agat Unit.

\section{Wednesday, May $12^{\text {th }}-$ Area 50 site visit with Curt Kessler}

We met Curt Kessler at Area 50 in the morning, searched transect E and saw that joga was reproducing, finding and marking 17 seedling, and an additional 4 seedlings on transect $\mathrm{F}$, however, no intermediate sized saplings or small trees. Also found a suspected Tabernaemontana rotensis on transect E marked with 2 orange flags. Searched transects M and N for Morton's vegetation plots, but could not find any. Forest was very disturbed and scrubby, apparently second growth. Approximately half of Area 50 appears to be scraped over, second-growth, and only a small core area of about 20 acres appears to be undisturbed primary forest. Invasive plants included mile-a-minute vine (Mikania scandens) and Siam weed (Chromalaena odorata) among several vines, and Vitex parviflora, a fast growing tree in disturbed areas among piled-up rocks and old junk from the wars. Curt said there are about 5-10 pigs within the enclosure, yielding a density of $0.21-0.41 \mathrm{pigs} / \mathrm{ha}$. 


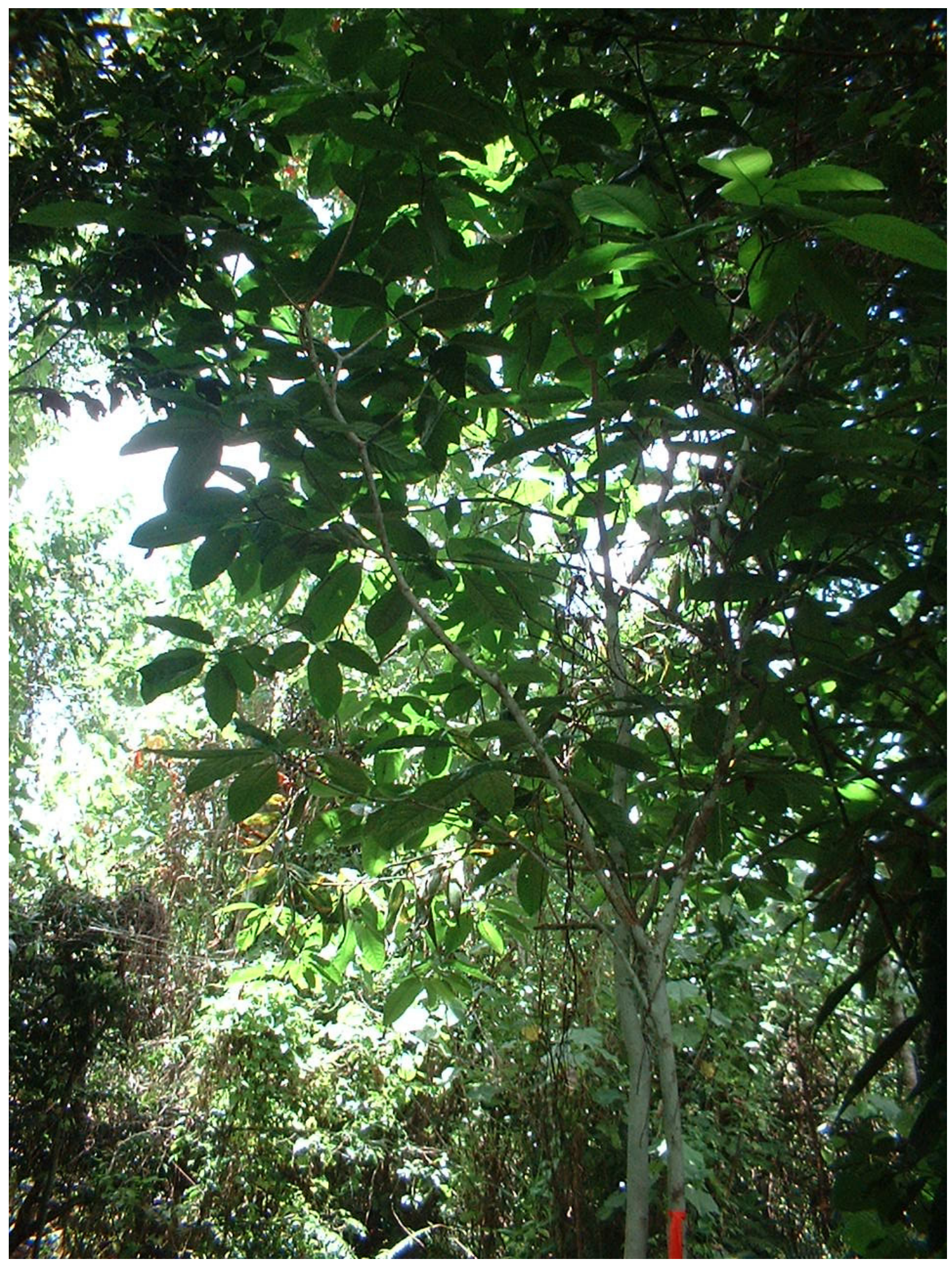

Tabernaemontana rotensis in Area 50. 
Thursday, May $13^{\text {th }}-$ South Guam and GNWR

We inventoried plants at Mt. Tenjo Trail unit of War in the Pacific National Historical Park, toured south of island, and inventoried plants at Piti Guns unit of WAPA. Mt. Tenjo trail was very burnt over and eroded by much ATV traffic. Some interesting shrubs remained, but most cover was grasses.

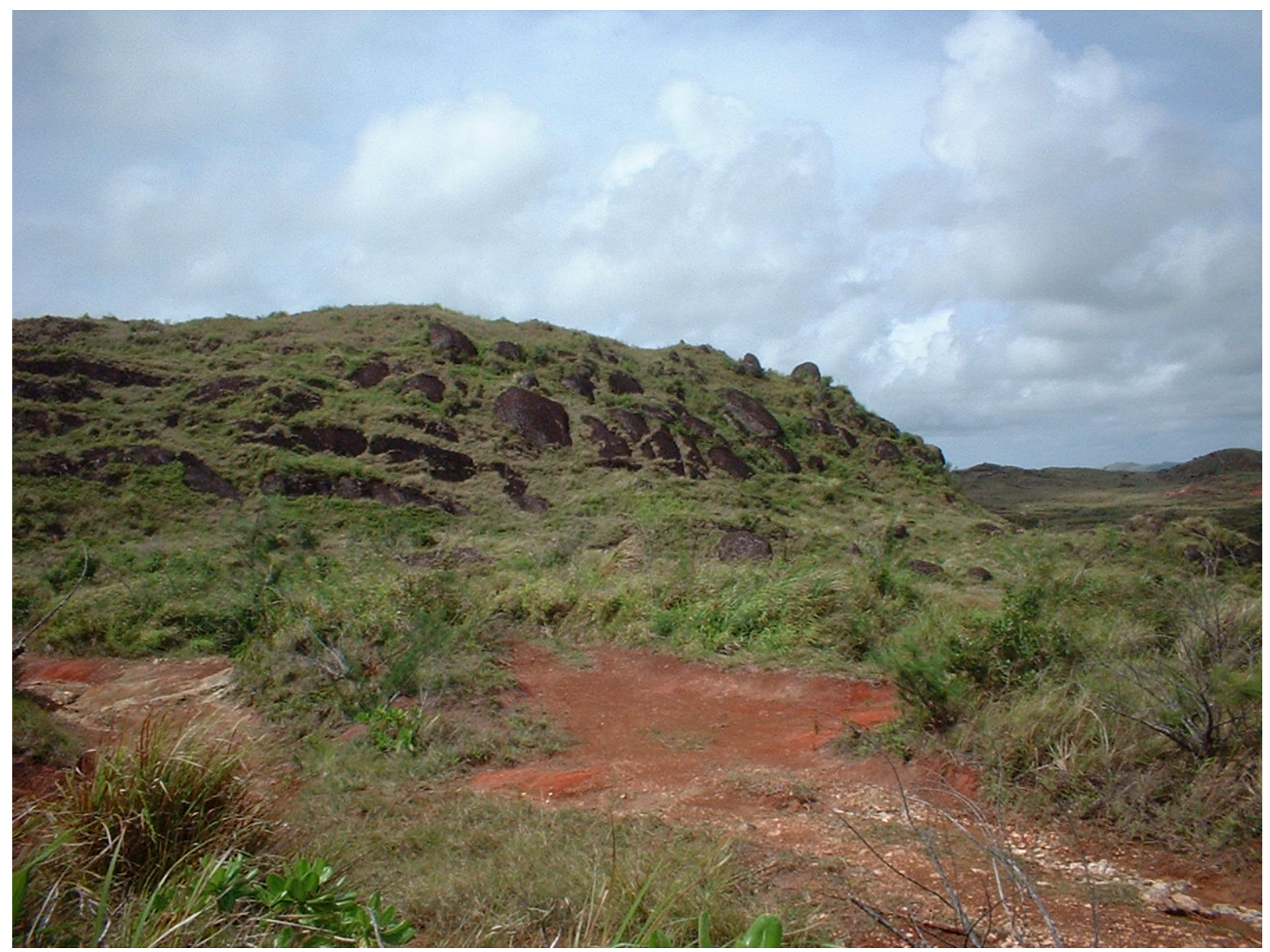

\section{Mt. Tenjo Trail unit of War in the Pacific National Historical Park}

We attempted to meet Curt Kessler at Area 50 at noon, but he could not come to the refuge. Found Gerry Deutscher and Earl Campbell at refuge headquarters. Gerry showed us correspondence in opposition to animal control at GNWR. Gerry reiterated that the refuge could use on-site documentation of the effects of feral animals on vegetation to justify management. Most of Gerry's time has been spent on securing facilities, power, and communications; consequently management has been delayed on the refuge. Earl and Gerry showed us DOQ imagery and said that more than 2/3 of northern Guam had been scraped in WWII and Vietnam. Earl contended that Guam's birds were well adapted for this type disturbance and that habitat should be able to recover well enough for birds. We observed, however, that much of the scraped area lacks real forest structure although many native species occur there. Gerry discussed private land holdings on AAFB that may require building a road through the refuge. There was also discussion about overlay refuge and the fact that AAFB would pull out of the overlay if critical habitat was designated for endangered species on Guam. Earl and Gerry mentioned management that would 
also occur in the Munitions Storage Area, 500 ha in size, apparently with a snake-proof fence and snake control inside. We hiked out in the coastal forest beyond refuge headquarters finding umumu, silver bush (Sophora tomentosa), and nigas (Pemphis acidula), but very few vines and other weeds.

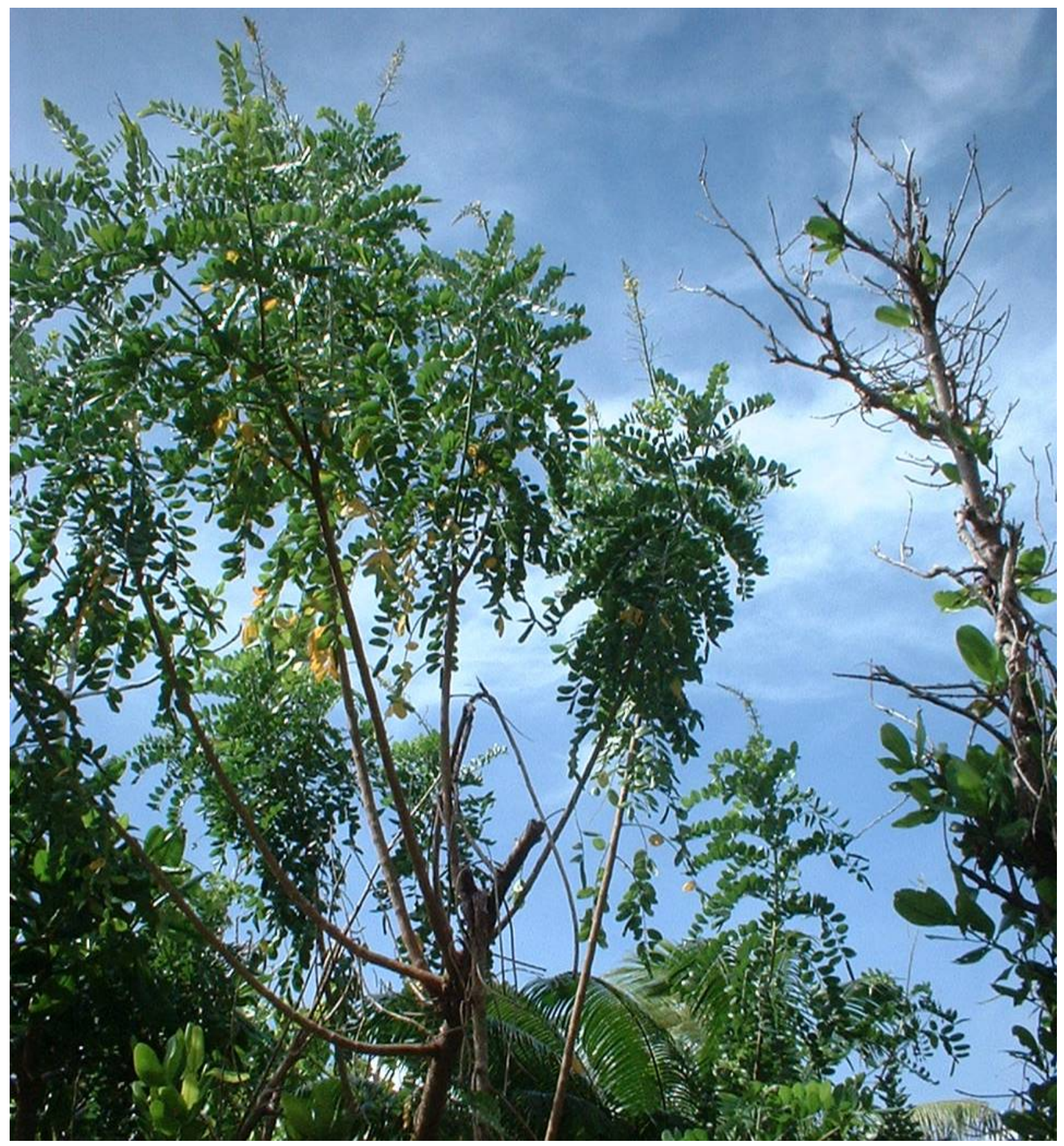

Silver bush (Sophora tomentosa) beyond refuge headquarters at Ritidian Point. 


\section{Friday, May $14^{\text {th }}-\mathrm{U}$ of Guam}

We attempted to get base pass to AAFB, but our paperwork was not at the visitor's center when we arrived. Met with Lynn Raulerson at U of Guam herbarium. Examined herbarium specimens of Serianthes nelsonii, Tabernaemontana, Pisonia grandis, Tinospora homosepala. Copied reports of WAPA survey from 1979 and Lena Quinata's vegetation survey of AAFB. Talked to Lynn for several hours. Lynn said that Tinospora was reduced to 4-5 individuals, all of which were male. Although Tabernaemontana rotensis was recognized as endemic on Guam and Rota, subsequent published work identified it as part of the widespread species Tabernaemontana pandacaqui. The FWS originally proposed listing Tabernaemontana rotensis with two other plant species, but withdrew the nomination after the change in nomenclature. Went to Asan Unit of WAPA at 2:00 PM and found the rare Tinospora vine covering tangantangan! Had dinner with Lynn at Le Tasi Miya, discussed the 47 million year history of Guam. Lynn said there were 200 B52's at NW field of AAFB during Vietnam era.

\section{Saturday, May $15^{\text {th }}$}

AM errands. Tried to locate Harmon Village, but this old Air Force complex had been destroyed years ago. Went to Dos Amantes point, then Faith book store on Harmon Loop Road to buy topographic maps. Went to GNWR and met briefly with Gerry Deutscher who welcomed us to go into the coastal forest beyond refuge headquarters. We passed through dense and thorny horizontal stands of alien limeberry or limondechina (Triphasia trifolia) laid down by typhoons. Found mature umumu trees, with about 20 seedlings under 2 of 12 trees. Saw a pig and pig and deer sign near base of cliff and a few patches of weedy vines. On return, found large patch of Tabernaemontana rotensis at switchback turnout on road to coast. It became clear to us that there are some differences in coastal limestone forests and plateau forest in abundance of species, such as umumu and joga among others.

\section{Sunday, May $16^{\text {th }}-$ Rota.}

Met with Stan (Lau) Taisacan who showed us Osmoxylon, Tabernaemontana and a rare fern at his house. We saw a Philippine sambar deer while we were lost above Songsong Village before we found his house. Stan said that Serianthes nelsonii trees were in bad shape after typhoon Pongsona and many were dying. Stan showed us the route to his ranch near the Sabana and where to find good forest, plants, and birds. We subsequently saw Miconesian Starlings (Aplonis opaca) (with Black Drongos), Cardinal Honeyeaters, Rufous Fantails (Rhipidura rufifrons), Rota Bridled White-eye, and Marianas Fruit Bat on his property, and a Mariana Fruit Dove (locally known as Paluman Totot) near the Sabana. We also saw Brown and Black Noddies (Anous stolidus and A. minutus), Red-footed Boobies (Sula sula), Red and White-tailed Tropicbirds (Phaethon rubricauda and P. lepturus), and White Terns (Gygis alba) at the bird sanctuary, and a Collared Kingfisher between the sanctuary and the latte quarry near the airport. Forest on Rota was very tall in stature and unfragmented in comparison to Guam, and we saw an area in the Sabana where Elaeocarpus joga was regenerating with intermediate-aged trees. We saw several rats on Rota, perhaps more abundant due to lack of BTS. 


\section{Monday, May $17^{\text {th }}$ - Area 50 and U of Guam}

We successfully obtained our AAFB base and went to Area 50. Curt Kessler arrived shortly thereafter to hunt pigs, so we worked on transects $\mathrm{E}$ and D while Curt hunted farther out. Curt shot a $~ 18$ month old boar. We found the Tabernaemontana tree and verified it, then tagged another 20 joga seedlings on transect D. After we met Curt, he said one of Morton's plots was right in the middle of transect $\mathrm{K}$. We found it and laid out a $300 \mathrm{~m}^{2}$ plot and identified some problems that need to be clarified by Morton in order to replicate his work. We need to find out how Morton defined stems and the implications for trees knocked over by typhoons. It seems that Morton's protocol may not address questions about regeneration and invasive plant cover that we are interested in. We looked at area 35, but it appeared to have been entirely cleared and had no forest with any integrity. We later met Lynn Raulerson at the herbarium and identified mwelel piut or Streblus pendulinus that we collected in Area 50, and we found that it was more common than we were led to believe. Lynn suggested an area that may be comparable to northern Guam on Rota near the airport.

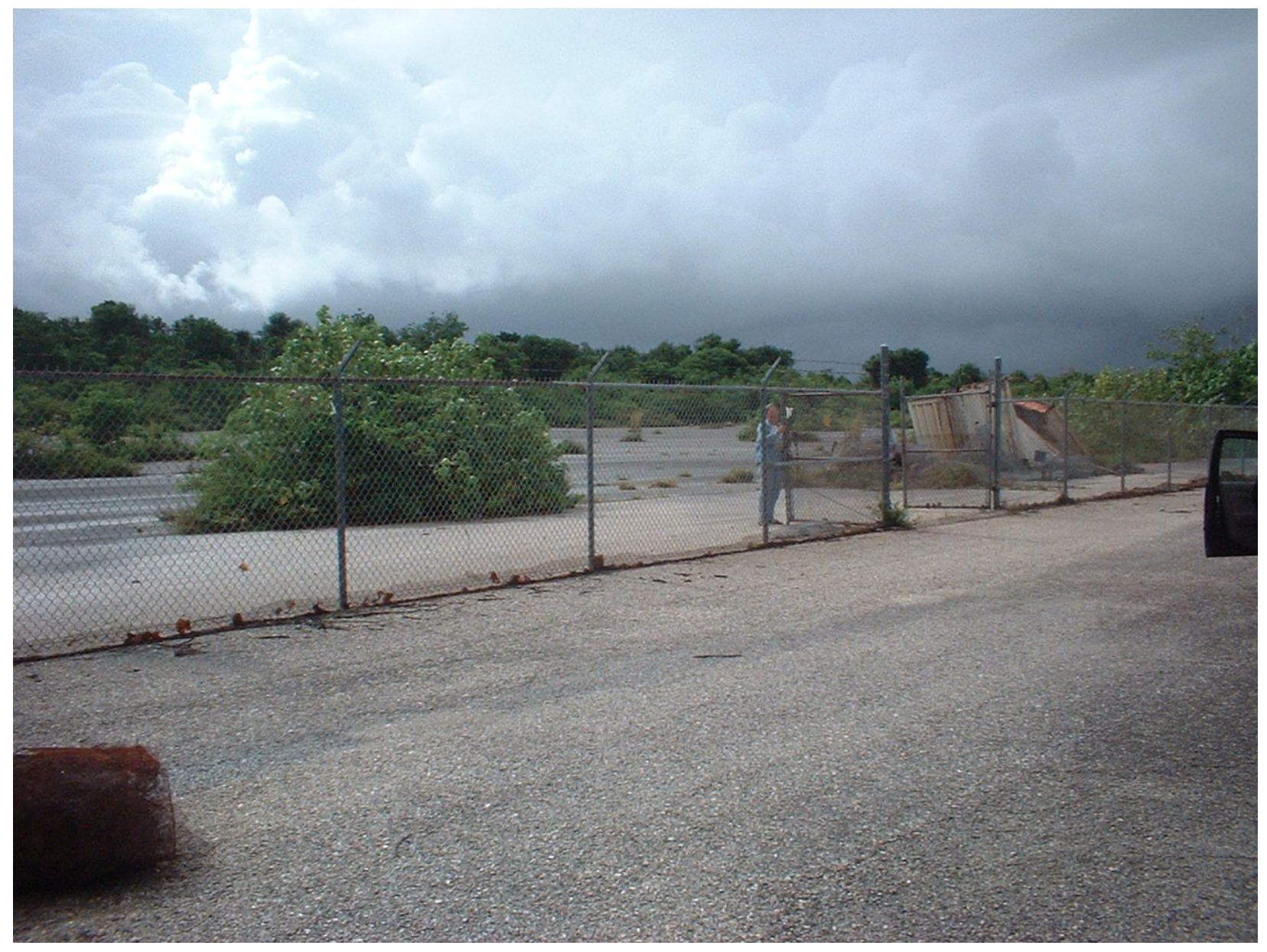

Area 50 fence and gate with edge vegetation in the background. 


\title{
Appendix II. Guam and CNMI Travel Itinerary, 2005
}

\author{
Monday, June $20^{\text {th }}-$ Guam
}

Arrived on Guam late PM, checked in to the Inn on the Bay in Agat.

\section{Tuesday, June $21^{\text {st }}-$ Guam}

Food provisioning in the AM.

WAPA PM- We met with Dwayne Minton and Jenny Drake (Resources Management Staff) at WAPA headquarters in the early afternoon to discuss their research on fire, erosion in tropical badlands, and impacts on coral reefs of southern Guam. Dwayne told us about the palynology work of Steve Athens and Jerome Ward that showed southern Guam to be forested in prehistoric times (Athens and Ward 2004). Dwayne has been working on estimating total sediment loads from a discrete watershed on to the reef in Asan Bay, and is now working towards estimating this on a larger scale of the landscape. We toured the existing offices which have been located mostly in the maintenance building since 2002. His office was in a cargo container with several other people. Dwayne told us that a new building was in the works to house park staff and provide a visitor center. He discussed the real problem of obtaining a vehicle from GSA on Guam which took 2 years because an exemption was not granted. Service was required by GSA to be done at an authorized facility, the nearest of which was located in Honolulu.

\section{Wedesday, June $2^{\text {nd }}-\quad$ GNWR, Ritidian Point}

We met with Anne Brooke early in the morning at entrance of GNWR and saw many examples of cycad scale on the escarpment road down to Ritidian Point. Anne has been coordinating efforts on cycad scale research and management and participating with R. Muniappan, T. Marler, and Aubrey Moore on ladybird beetle releases to control scale. Anne showed us beetles at a release site that appeared to be thriving and having some effect on the scale. We learned that both male and female forms of the scale infested cycads, and most of the damage was done by the larger female scale.

We met with Gerry Deutscher in the mid morning as he was dealing with generator failure at the refuge office. They would be on solar power and without air conditioning until a bearing could be shipped. Gerry had been doing some deer and pig removal on the refuge as part of an informal reduction program. There is currently no ungulate activity monitoring on the refuge. Gerry was also engaged in a small scale restoration in the vicinity of the office by pulling out tangantangan and transplanting an assortment of native seedlings which Anne Brooke had been growing from locally collected seeds. He had been concerned about trees such as seeded breadfruit, joga, umumu, gulos, and ifit. Gerry explained the changes in the proposed Area 50 research project which was now slated for a 109 acre area near Potts junction. He said that Earl Campbell and Gordon Rodda were in the process of finalizing the change, but a snag in the transaction would have to be worked out. Gerry said although the area is much larger than Area 50, it may be more problematic to construct a snake barrier around the entirety of it. The limestone forest of the new area appeared to be of shorter stature and more representative of secondary succession. We also met briefly Richard Bishoff, BTS research manager, and Michelle Christy while at GNWR. 


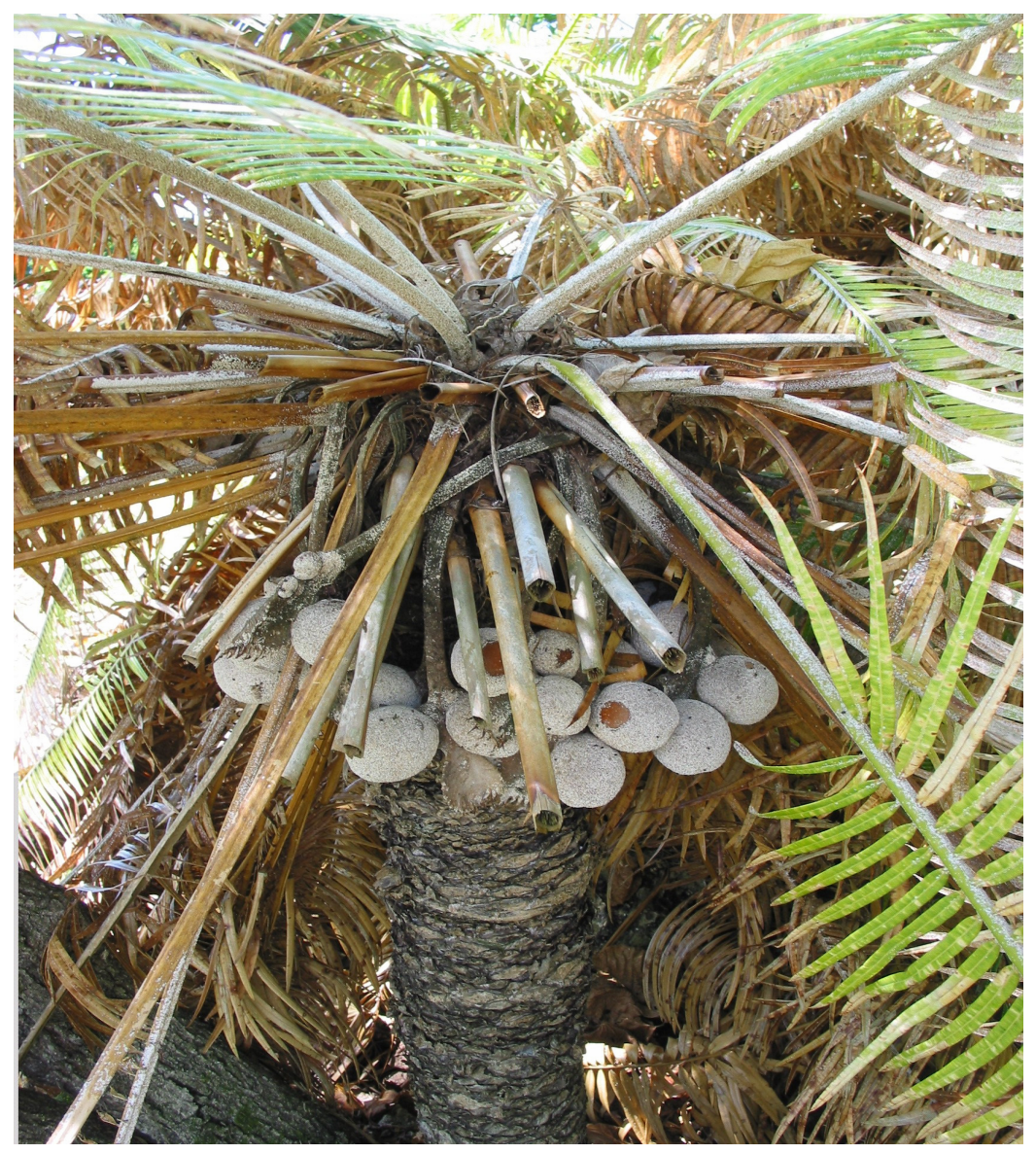

Cycad with scale infestation along road to Ritidian Point. 


\section{Thursday, June $23^{\text {rd }}$-WAPA Sabana research field trip in AM}

We participated with Dwayne and Jenny in their Sabana erosion field study. We could immediately see the difficulty of relocating study plots within swordgrass (Miscanthus floridulus), and gained first-hand experience with tunneling through the grass to find flags and pins. We saw four savanna subtypes: swordgrass, mixed grass, fern-dominated scars, and badlands. Large animals did not appear to be a major issue in the study area. We saw a sequence of burned areas in regeneration and eroding barren areas. After our trip to the sabana, we stopped at the Asan Beach Unit to photograph the vine Tinospora homosepala, a species of concern.

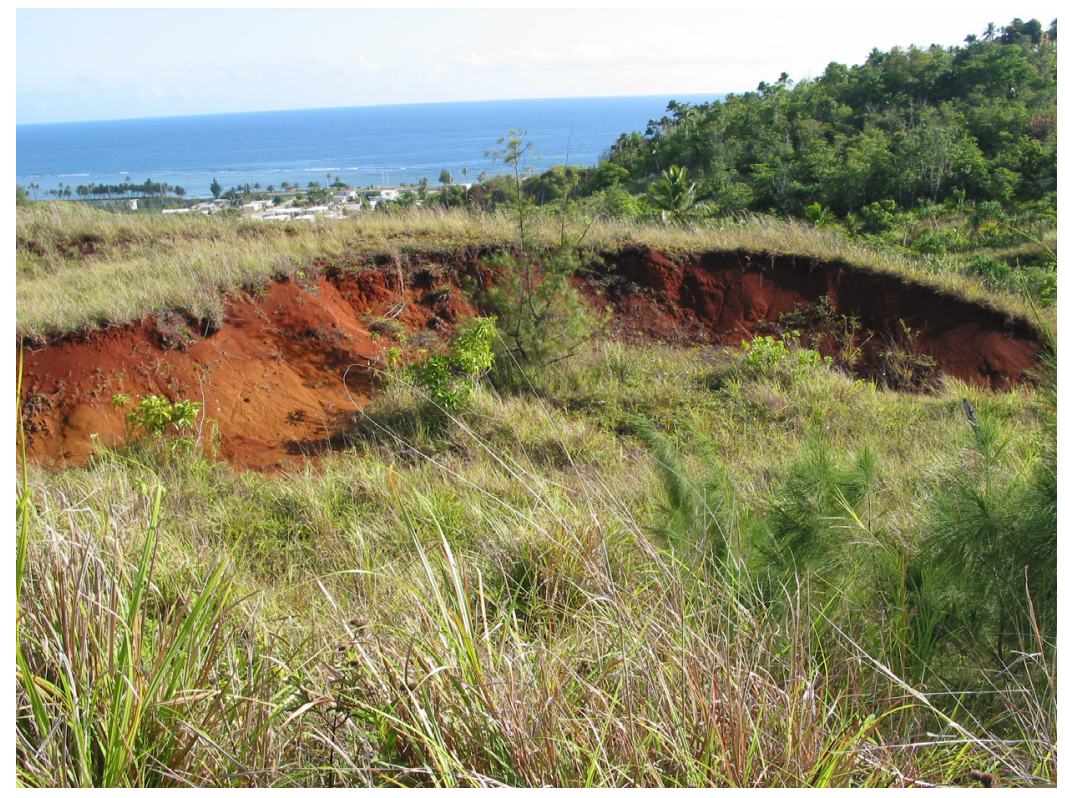

Sabana vegetation within WAPA.

UOG Library PM- We reviewed twelve early volumes of Micronesica for annotated bibliography. We found a stack of theses, but did not locate Dustin Janecke's thesis on bats and cycads- apparently he has not finished yet.

\section{Friday, June $24^{\text {th }}-$ AAFB}

Escorted to Area 50 in AM. Located joga seedlings from last year. We found 31 of 51 tags from 2004, but only 9 seedlings remained alive. Some survivors also appeared to be set back in height by browsing. Some new seedlings had germinated in the interim. Transects appeared to not have much recent traffic- very hard to navigate.

Meeting with U.S. Navy environmental staff in PM. Robert Wescom, COMNAVMAR Region Natural Resources Program Manager, Lt. Kenneth L. Culbreath, CEC, USN COMNAVREGMAR, Region Environmental Officer/Region Environmental Coordinator, and Anne Brooke, Naval Magazine biologist. We discussed USGS organizational matters and our particular research expertise. Wescom mentioned that legacy funds for research on DOD lands were "drying up." Anne briefed us on her observations of ungulate sign, and the difficulty in doing road counts of deer. She has one deer collared, and it has been difficult to dart and capture a large enough sample to monitor. She also explained the monitoring scheme established by Dueñas Co. 
40 points were selected on Navy lands, ca. 15 on the Naval Magazine and a few at Orote, Haputo, and other Navy sites. At each point there were four transects, along which trees, canopy cover, and ground cover were sampled. There was no original sampling for ungulate activity, but Anne did some informal sampling when she re-monitored the points/transects.

\section{Saturday, June $25^{\text {th }}$ - GNWR field trip to Jinapsan Beach, umumu (Pisonia grandis ) trees.}

We found many umumu trees, undisturbed, for the most part, on rough karst substrates lacking soil near the coast. On substrates with developed soils, however, it appeared that activity by feral pigs or deer was causing major disturbance and interrupting regeneration processes. No umumu seedlings were observed during this outing.

\section{Sunday, June $26^{\text {th }}$}

Traveled around southern Guam, Tarzan Falls, Merizo and Umatac villages. Attempted to hike to Cetti Bay, but unbearable midday heat made us turn back.

\section{Monday, June $27^{\text {th }}-$ Travel to Rota}

Limestone forest east of airport, Mochong village, As Matmos in AM, South Coast, Afatung Wildlife Management Area, Bird Sanctuary in PM. Saw a Mariana Crow flying high over the ridge of the Sabana. Tried to contact Rob Ulloa of CNMI DFW by phone and drove by his office.

\section{Tuesday, June $28^{\text {th }}$-Met Stan Taisacan, Sabana Conservation Area AM}

At Stan Taisacan's land near Uylulan Hulo, we saw Rota Bridled White-eye, Fruit Bats and other birds. Stan showed up some time later and told us about the problems with Osmoxylon mariannense bark stripping by deer. We told Stan about cycad scale on Guam and he showed us scale on guava which had recently showed up. On the drive out, Stan showed us 3 Serianthes nelsonii trees by the side of the road, one of which was killed by last year's typhoon. Stan estimated that 1 in 3 Serianthes is lost during each typhoon, lowering the 121 known live trees on the island to about 80-90. Stan said that he learned to cover seed pods with fine mesh to keep predatory arthropods from eating seeds before maturity. Stan also showed us an exclosure with Tabernaemontana rotensis, told us some other exclosures had burned. 


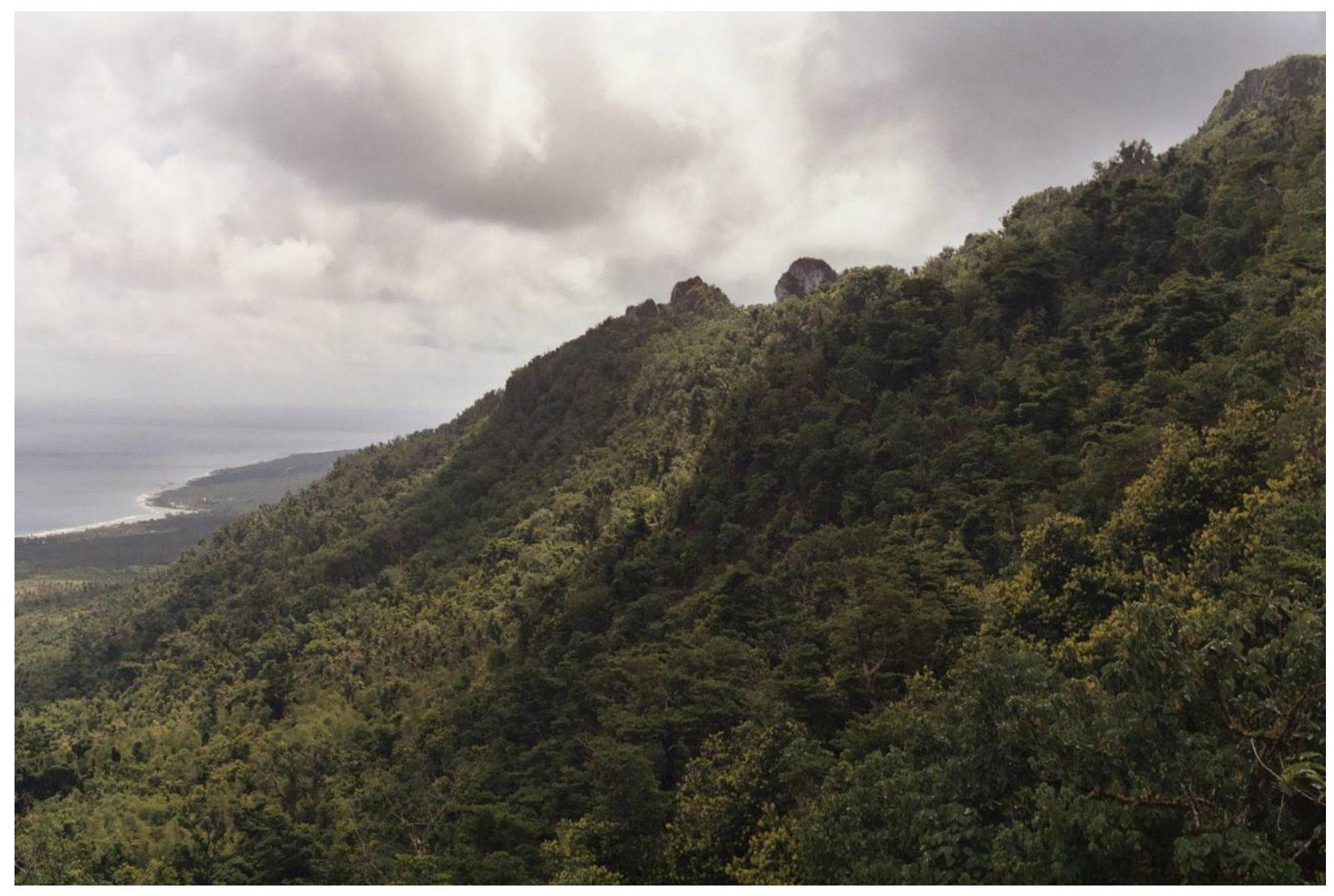

View of forest from Stan Taisacan's property looking towards Uyulan Hulo. Several Mariana Fruit Bats (Pteropus mariannus) flew by during our visit.

An unsolicited local islander discussed Rotanese politics with us in PM. Saw nigas or Pemphis acidula growing as trees at the swimming hole. Tried to contact Rob Ulloa of CNMI DFW by phone and drove by his office. Gasoline cost $\$ 3.05$ per gallon. 


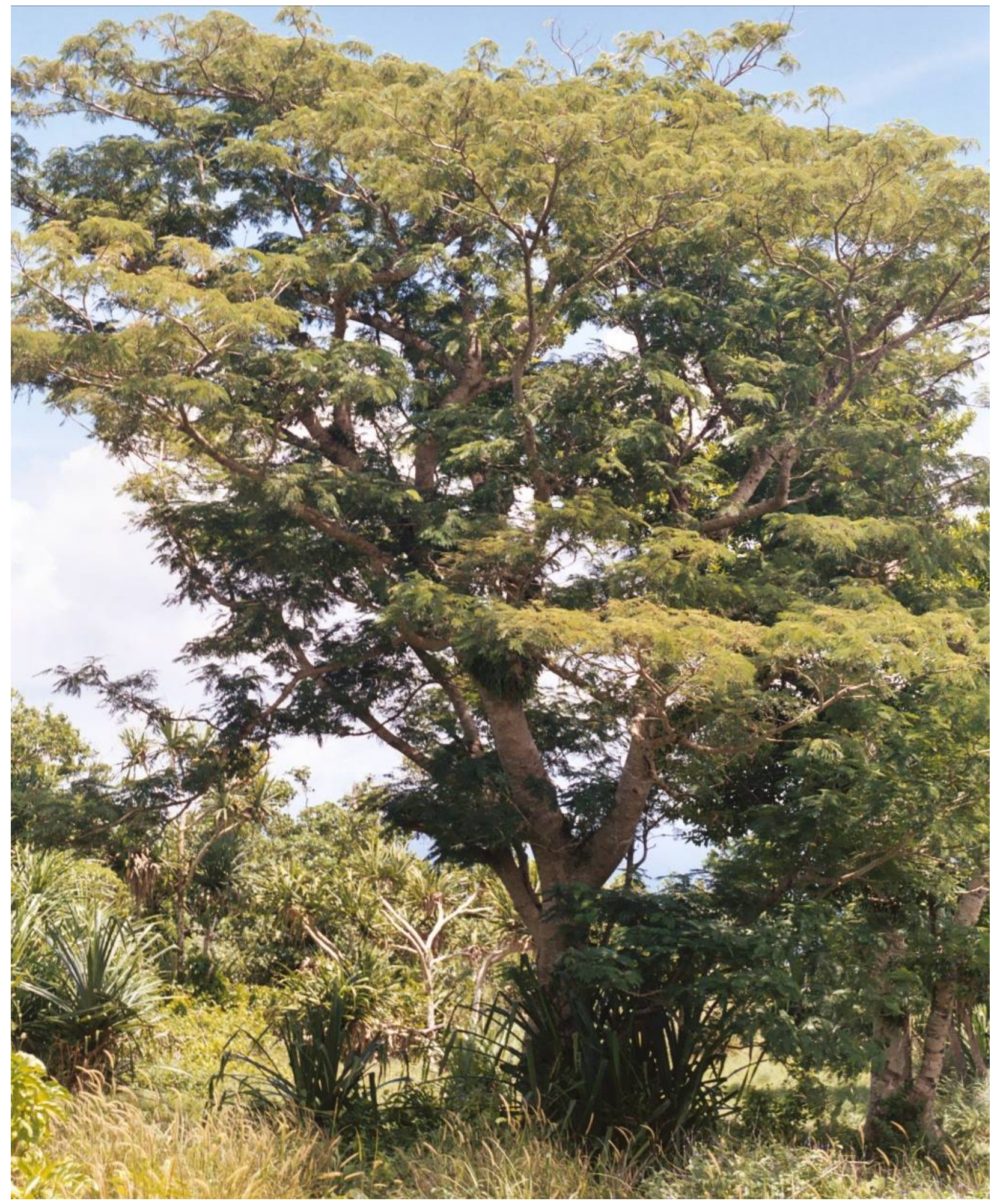

Serianthes nelsonii tree growing near the Taisacan property on Rota. 


\section{Wednesday, June $29^{\text {th }}$-Travel to Saipan,}

AMME-After arriving on Saipan, we met with Chuck Sayon, Superintendent of AMME in the late morning. The park had been visited the previous day by the Emperor of Japan and associated crowds and media. Chuck discussed his idea of creating a natural area reserve for the mangrove wetland within the park. He told us there was a USGS study of hydrology addressing how salt water flows in to the isolated wetland, and a study by Nathan Johnson on the status of Nightingale Reed-warblers. He said he never received a final report from Steve Mosher's University of Idaho study on Reed-warblers. The mangrove wetland was the major natural resource in need of protection and restoration in the park.

CNMI DFW- In the afternoon, we met with Gayle Berger at CNMI DFW. Gayle was in the process of preparing the comprehensive wildlife plan for the CNMI. She told us of many research needs that would probably be identified in the plan, many of these focused on birds and bird habitats. Saipan has been coming to terms with the fact that a population of BTS has become established on the island, therefore, some research will be needed to assess habitat quality on other islands where birds may be translocated in the future, such as Sarigan, Anatahan, and Agiguan. Another research need stemmed from the fact that an HCP credit system had been set up for Nightingale Reed-warblers before the Asian economic crisis. After the crisis, however, resort construction has ceased and the need for agricultural lands increased, but small scale farmers could not afford the HCP credit system. The relative value of tangantangan vs. native forest for Nightingale Reed-warblers, part of Mosher's uncompleted study, is needed to address this issue.

\section{Thursday, June $30^{\text {th }}$}

We spent most of the day in the upland areas of Marpi district and northern end of Saipan. Set out on the trail in the morning through the Laderan Tangke Conservation Area to observe limestone forest of Saipan. Toured some of the higher elevation points on the island to view forests in the area. Encountered a cattle watering hole with several foraging Mariana Swiftlets. Went to base of Suicide cliffs to look for Megapodes, but with no success.

\section{Friday, July $1^{\text {st }}$}

Returned to Guam, met with Lynn Raulerson and Joan Yoshioka at UOG in the afternoon. Lynn showed us an interesting new book by Scott Vogt and Laura Williams, the Common Flora and Fauna of the Mariana Islands.

Late PM we got boarding passes and checked our luggage for the early Continental flight to Honolulu.

\section{Saturday, July $2^{\text {nd }}$}

Returned to Hawaii, met Leslie Haysmith and Penny Latham of NPS Inventory and Monitoring in customs and immigration line while waiting for flight from Guam to Honolulu. 


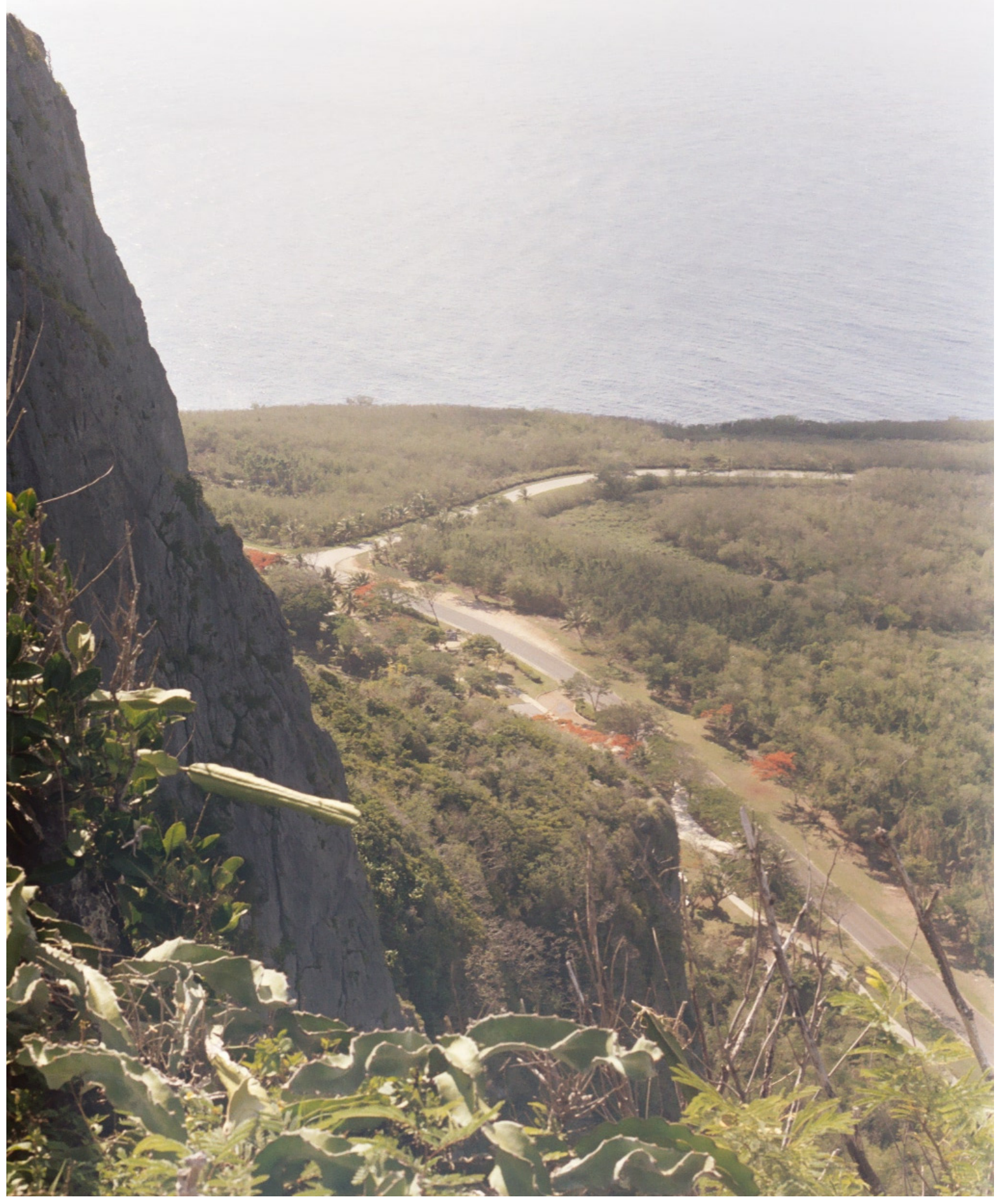

View of war memorials from top of Suicide Cliffs on Saipan. 


\section{Appendix III. Guam and CNMI Contacts}

Tino Aguon

Division of Aquatic and Wildlife Resources, Guam Department of Agriculture

P.O. Box 2950

Agana, Guam 96910

Anne Brooke

Wildlife Biologist

Guam National Wildlife Refuge

POB 8134, MOU-3

Dededo, Guam 96929

brookea@guam.navy.mil

Anne_Brooke@fws.gov

(671) 339-7051

Gayle M. Berger

Natural Resources Planner

CNMI Div. of Fish and Wildlife

Caller Box 10007, Saipan MP 96950

Ph: 670-664-6025; Fax: 670-664-6060

Earl Campbell

US Fish and Wildlife Service

Pacific Islands Fish and Wildlife Office

300 Ala Moana Blvd

Honolulu, HI 96850

(808) 226-6076

E-mail: Earl_Campbell@fws.gov

Michelle Christy, Ph.D.

Brown Treesnake Project

P.O. Box 8255, MOU-3

Dededo, GU 96929-8255

Phone: (671) 255-4015; FAX: (671) 355-4016

E-mail: michelle.christy@colostate.edu

\section{Gerry Davis}

Chief, Division of Aquatic and Wildlife Resources,

Guam Department of Agriculture

P.O. Box 2950

Agana, Guam 96910

Phone: (671) 735-3955; FAX: (671) 734-6570

E-mail: gdavis@mail.gov.gu

Gerry Deutscher

Refuge Manager, Guam National Wildlife Refuge

P.O. Box 8134, MOU-3

Dededo, Guam 96929

Phone: (671) 355-5096; FAX: (671) 355-5098
Curt Kessler

US Fish and Wildlife Service

Pacific Islands Fish and Wildlife Office

300 Ala Moana Blvd

Honolulu, HI 96850

Curt_Kessler@fws.gov

Shelly Kremer

Division of Fish and Wildlife, Saipan

Lower Base

Box 10007

Saipan, MP 96950

Tele: 670-664-6013

Fax: 670-664-6060

E-mail: skremer@vzpacifica.net

David Limitiaco

Forestry and Soil Resources Division

192 Dairy Road

Mangilao, Guam 96913

Phone: (671) 735-3949; FAX: (671) 734-0111

Haldre Rogers--USGS

Brown Treesnake Rapid Response Team Coordinator

Phone (24 hours): (671) 777-HISS (4477)

P.O 8255, MOU-3

Dededo, Guam 96929

E-mail: haldre_rogers@usgs.gov

Chuck Sayon

Site Manager/Park Ranger

American Memorial Park

P.O. Box 5198 CHRB

Saipan, MP 96950

(670) 234-7207

E-mail: Chuck_Sayon@nps.gov

Daniel S. Vice,

Assistant USDA - Wildlife Services

1060 Route 16,

Suite 103C

Barrigada Heights, Guam 96921

Phone: (671) 635-4400; FAX: (671) 635-4401

E-mail: Daniel.S.Vice@usda.gov

Diane Vice

Division of Aquatic and Wildlife Resources,

Guam Department of Agriculture

P.O. Box 2950

Agana, Guam 96910 


\section{Appendix IV. Bird Observations}

\section{Birds Observed on Guam (2004 and 2005)}

Red-footed Booby (Sula sula)

Pacific Reef Heron (Egretta sacra)

Yellow Bittern (Ixobrychus sinensis)

White Tern (Gygis alba)

Black Francolin (Francolinus francolinus)

Philippine Turtle Dove (Streptopelia bitorquata)

Rock Dove (Columba livida)

Black Drongo (Dicrurus macrocercus)

Eurasian Tree Sparrow (Passer montanus)

\section{Birds Observed on Rota (2004 and 2005)}

Black Drongo (Dicrurus macrocercus)

Micronesian Starling (Aplonis opaca)

Cardinal Honeyeater (Myzomela rubratra)

Rufous Fantail (Rhipidura rufifrons)

Rota Bridled White-eye (Zosterops conspicillatus rotensis)

Mariana Fruit Dove (Ptilinopus roseicapilla)

White-throated Ground-dove (Gallicolumba xanthonura xanthonura)

Philippine Turtle-dove (Streptopelia bitorquata)

Mariana crow (2005) (Corvus kubaryi)

Collared Kingfisher (Halcyon chloris)

Brown Noddy (Anous stolidus)

Black Noddy (Anous minutus)

Red-footed Booby (Sula sula)

Brown Booby (Sula leucogaster)

Red-tailed Tropicbird (Phaeton rubricauda)

White-tailed Tropicbird (Phaeton lepturus)

Pacific Reef Heron (Egretta sacra)

White Tern (Gygis alba)

\section{Birds Observed on Saipan (2005)}

Micronesian Starling (Aplonis opaca)

Cardinal Honeyeater (Myzomela rubratra)

Rufous Fantail (Rhipidura rufifrons)

Bridled White-eye (Zosterops conspicillatus conspicillatus)

Golden White-eye (Cleptornis marchei)

Mariana Fruit Dove (Ptilinopus roseicapilla)

Philippine Turtle-dove (Streptopelia bitorquata)

Collared Kingfisher (Halcyon chloris)

Mariana Swiftlet (Aerodramus bartschi) 
Appendix V. Preliminary checklist of vascular plants at War in the Pacific National Historical Park (WAPA), Guam, based on site visits in May 2004.

\begin{tabular}{|c|c|c|c|c|c|c|c|c|c|c|}
\hline Group/Family & Scientific Name & $\begin{array}{c}\text { Common } \\
\text { Name* }\end{array}$ & Nativity & $\begin{array}{l}\text { Agat } \\
\text { Beach }\end{array}$ & $\begin{array}{c}\text { Asan } \\
\text { Beach }\end{array}$ & $\begin{array}{c}\text { Asan } \\
\text { Overlook }\end{array}$ & $\begin{array}{c}\text { Piti } \\
\text { Guns }\end{array}$ & $\begin{array}{l}\text { Mt. } \\
\text { Tenjo }\end{array}$ & $\begin{array}{c}\text { Mt. } \\
\text { Alifan** }\end{array}$ & Abundance \\
\hline \multicolumn{11}{|l|}{ FERNS } \\
\hline Aspleniaceae & Asplenium polyodon Forster f. & Spleenwort & I & & $\mathrm{x}$ & & & & & Uncommon \\
\hline Blechnaceae & Blechnum orientale $\mathrm{L}$. & Blechnum & I & & & & & $\mathrm{x}$ & & Common \\
\hline Gleicheniaceae & Dicranopteris linearis (Burm. F.) Underw. & Mana & I & & & & & $\mathrm{x}$ & & Common \\
\hline Lindsaeceae & Lindsaea ensifolia Swartz & nen & I & & & & & $\mathrm{x}$ & & Uncommon \\
\hline Lindsaeceae & Sphenomeris chinensis (L.) Maxon & ncn & I & & & & & $\mathrm{x}$ & & Uncommon \\
\hline Lycopodiaceae & Lycopodiella cernua (L.) Pic. Serm. & Club moss & I & & & & & $\mathrm{x}$ & & Common \\
\hline Nephrolepidaceae & Nephrolepis biserrata (Swartz)Schott & Swordfern & I & & $\mathrm{x}$ & & $\mathrm{x}$ & & & Common \\
\hline Nephrolepidaceae & Nehrolepis hirsutula (Forster f.) Presl & Swordfern & I & & $\mathrm{x}$ & & $\mathrm{x}$ & & & Common \\
\hline Nephrolepidaceae & Nephrolepis multiflora (Roxb.) Jarrett ex Morton & Swordfern & I & & & & & $\mathrm{x}$ & & Common \\
\hline Polypodiaceae & Belvisea spicata (L.f.) Mirbel ex Copeland & $\begin{array}{l}\text { ncn } \\
\text { Pugua }\end{array}$ & I & & & & & $\mathrm{x}$ & & Uncommon \\
\hline Polypodiaceae & Davallia solida (Forster f.) Swartz & machena & I & & & & & $\mathrm{x}$ & & Uncommon \\
\hline Polypodiaceae & Phymatosorus scolopendria (Burm f.) Pichi. Serm. & nen & I & $\mathrm{x}$ & $\mathrm{x}$ & & $\mathrm{x}$ & & & Common \\
\hline Polypodiaceae & Pyrrosia lanceolata (L.) Farwell & $\begin{array}{l}\text { ncn } \\
\text { Brittle } \\
\text { maidenhair }\end{array}$ & I & & $\mathrm{x}$ & & & & & Uncommon \\
\hline Pteridaceae & Adiantum tenerum Swartz & fern & A & & & & $\mathrm{x}$ & & & Rare \\
\hline Pteridaceae & Pteris vittata $\mathrm{L}$. & Ladder brake & A & $\mathrm{x}$ & $\mathrm{x}$ & & $\mathrm{x}$ & $\mathrm{x}$ & $\mathrm{x}$ & Common \\
\hline Schizaeeceae & Lygodium microphyllum (Cavanilles) R. Brown & $\mathrm{ncn}$ & I & & & & & $\mathrm{x}$ & & Uncommon \\
\hline Thelypteridaceae & Christella parasitica (L.) H. Lev. & $\mathrm{ncn}$ & I & & $\mathrm{x}$ & & & & & Uncommon \\
\hline Thelypteridaceae & Thelypteris opulenta (Kaulf.) Fosb. & $\mathrm{ncn}$ & I & & & & $\mathrm{x}$ & & & Uncommon \\
\hline Thelypteridaceae & Thelypteris unita (L.) C. V. Morton & $\mathrm{ncn}$ & I & & & & & $\mathrm{x}$ & & Uncommon \\
\hline \multicolumn{11}{|l|}{ MONOCOTS } \\
\hline Agavaceae & Cordyline fruticosa (L.) Goepp. & $\begin{array}{l}\text { Baston de San } \\
\text { Jose, ti }\end{array}$ & A & & & & $\mathrm{x}$ & & & $\begin{array}{l}\text { Uncommon, } \\
\text { cult. }\end{array}$ \\
\hline Amaryllidaceae & Crinum asiaticum L.? & Piga-Palayi & I & & $\mathrm{x}$ & & & & & $\begin{array}{l}\text { Rare, cult. } \\
\text { Uncommon, }\end{array}$ \\
\hline Amaryllidaceae & Hymenocallis littoralis (Jacq.) Salisb. & Spider lily & A & $\mathrm{x}$ & $\mathrm{x}$ & & $\mathrm{x}$ & & & cult. \& nat. \\
\hline
\end{tabular}




\begin{tabular}{|c|c|c|c|c|c|c|c|c|}
\hline Araceae & Anthurium sp. & Anthurium & A & & & & $\mathrm{x}$ & $\begin{array}{l}\text { Uncommon, } \\
\text { cult. }\end{array}$ \\
\hline Araceae & Epipremnum pinnatum (L.) Engl. & $\begin{array}{l}\text { Pothos, Taro } \\
\text { vine }\end{array}$ & A & & & & $\mathrm{x}$ & $\begin{array}{l}\text { Uncommon, } \\
\text { cult. }\end{array}$ \\
\hline Araceae & Syngonium sp. (maybe S. podophyllum Schott) & Syngonium & A & & & & $\mathrm{x}$ & $\begin{array}{l}\text { Uncommon, } \\
\text { cult. }\end{array}$ \\
\hline Arecaceae & Cocos nucifera L. & $\begin{array}{l}\text { Coconut palm, } \\
\text { niyog }\end{array}$ & Chamorro & $\mathrm{x}$ & $\mathrm{x}$ & $\mathrm{x}$ & & $\begin{array}{l}\text { Common, } \\
\text { cult. \& nat. }\end{array}$ \\
\hline Arecaceae & Dypsis lutescens (H. Wendland) Beentje \& Dransfield & $\begin{array}{l}\text { Golden fruited } \\
\text { palm }\end{array}$ & A & & & $\mathrm{x}$ & & $\begin{array}{l}\text { Uncommon, } \\
\text { cult. }\end{array}$ \\
\hline Arecaceae & Heterospathe elata Scheffer & Palma Brava & I & & & & $\mathrm{x}$ & Uncommon \\
\hline Arecaceae & Veitchia merrillii (Beccari) Moore & Manilla palm & A & & & $\mathrm{x}$ & & $\begin{array}{l}\text { Uncommon, } \\
\text { cult. }\end{array}$ \\
\hline Commelinaceae & Tradescantia spathacea Sw. & $\begin{array}{l}\text { Oyster plant } \\
\text { Umbrella }\end{array}$ & A & & & $\mathrm{x}$ & & $\begin{array}{l}\text { Rare, cult. } \\
\text { In one bed }\end{array}$ \\
\hline Cyperaceae & Cyperus alternifolius L. & sedge & A & $\mathrm{x}$ & & & & Uncommon \\
\hline Cyperaceae & Cyperus ligularis L. & Rocket sedge & A & $\mathrm{x}$ & & & & Uncommon \\
\hline Cyperaceae & Cyperus polystachyos Rottb. & $\mathrm{nen}$ & I & & & & $\mathrm{x}$ & Common \\
\hline Cyperaceae & Cyperus sp. & nen & Unknown & & & & $\mathrm{x}$ & Uncommon \\
\hline Cyperaceae & Eleocharis geniculata (L.) Roemer \& Schultes & Spikerush & I & & & & $\mathrm{x}$ & Common \\
\hline Cyperaceae & Fimbristylis autumnalis (L.) Roemer \& Schultes & $\mathrm{nen}$ & I & & & & $\mathrm{x}$ & Common \\
\hline Cyperaceae & Fimbristylis cymosa R. Br. & nen & I & $\mathrm{x}$ & $\mathrm{x}$ & & & Common \\
\hline Cyperaceae & Fimbristylis dichotoma (L.) Vahl & $\mathrm{nen}$ & I & & & $\mathrm{x}$ & $\mathrm{x}$ & Uncommon \\
\hline Cyperaceae & Machaerina mariscoides (Gaud.) J. H. Kern & $\mathrm{ncn}$ & I & & & & $\mathrm{x}$ & Uncommon \\
\hline Cyperaceae & Rhynchospora rubra (Lour.) Makino & $\mathrm{nen}$ & I & & & & $\mathrm{x}$ & Uncommon \\
\hline Cyperaceae & $\begin{array}{l}\text { Scirpus littoralis Shrader var. thermalis (Trabut) } \mathrm{T} \text {. } \\
\text { Koyama }\end{array}$ & Bulrush & I & $\mathrm{x}$ & & & & Uncommon \\
\hline Flagellariaceae & Flagellaria indica L. & $\begin{array}{l}\text { Bejuco halum- } \\
\text { tano }\end{array}$ & I & & $\mathrm{x}$ & & & Common \\
\hline Juncaceae & Juncus tenuis Willd. & Rush & A & & & & $\mathrm{x}$ & Uncommon \\
\hline Liliaceae & Dianella ensifolia (L.) DC. & $\mathrm{ncn}$ & I & & & & $\mathrm{x}$ & Rare \\
\hline Musaceae & Musa sp. & Banana & A & $\mathrm{x}$ & & & & Rare, cult. \\
\hline Orchidaceae & Arundina graminifolia (D. Don) Hochreutiner & Bamboo orchid & A & & & & $\mathrm{x}$ & Common \\
\hline Orchidaceae & Calanthe triplicata (Williem) Ames? & $\mathrm{nen}$ & I & & & & $\mathrm{x}$ & Uncommon \\
\hline
\end{tabular}




\begin{tabular}{|c|c|c|c|c|c|c|c|c|}
\hline Orchidaceae & Spathoglottis plicata Blume & $\begin{array}{l}\text { Phillipine } \\
\text { ground orchid }\end{array}$ & $\mathrm{A}$ & & & $\mathrm{x}$ & $\mathrm{x}$ & Uncommon \\
\hline Pandanaceae & Pandanus tectorius Sol. ex Park. & Kafu & I & $\mathrm{x}$ & $\mathrm{x}$ & $\mathrm{x}$ & & Uncommon \\
\hline Poaceae & Axonopus compressus (Sw.) Beauv. & Carpet grass & A & $\mathrm{x}$ & $\mathrm{x}$ & & $\mathrm{x}$ & Common \\
\hline Poaceae & Brachiaria sp. & Para grass & A & $\mathrm{x}$ & $\mathrm{x}$ & & & Uncommon \\
\hline Poaceae & Cenchrus echinatus L. & Sand bur & A & $\mathrm{x}$ & $\mathrm{x}$ & & & Common \\
\hline Poaceae & Chloris barbata (L.) Sw. & $\begin{array}{l}\text { Swollen } \\
\text { fingergrass }\end{array}$ & A & $\mathrm{x}$ & $\mathrm{x}$ & $\mathrm{x}$ & & Uncommon \\
\hline Poaceae & Chrysopogon aciculatus (Retz.) Trin. & $\begin{array}{l}\text { Inifuk, Golden } \\
\text { beardrass }\end{array}$ & I & $\mathrm{x}$ & $\mathrm{x}$ & & $\mathrm{x}$ & Common \\
\hline Poaceae & Coix lachryma-jobi L. & Job's tears & A & & $\mathrm{x}$ & & & Uncommon \\
\hline Poaceae & Cynodon dactylon L. var. dactylon & $\begin{array}{l}\text { Grama, } \\
\text { Bermuda grass }\end{array}$ & A & $\mathrm{x}$ & $\mathrm{x}$ & & $\mathrm{x}$ & Common \\
\hline Poaceae & Dactylotenium aegyptium (L.) Willd. & Crowfoot grass & A & $\mathrm{x}$ & $\mathrm{x}$ & & & Common \\
\hline Poaceae & Dicanthium caricosum (L.) A. Camus & $\mathrm{ncn}$ & A & $\mathrm{x}$ & $\mathrm{x}$ & $\mathrm{x}$ & $\mathrm{x}$ & Common \\
\hline Poaceae & Digitaria ciliaris (Retz.) Koel. & Crabgrass & I & & & & $\mathrm{x}$ & Uncommon \\
\hline Poaceae & Digitaria insularis (L.) Mez ex Ekman & $\mathrm{ncn}$ & A & $\mathrm{x}$ & $\mathrm{x}$ & $\mathrm{x}$ & & Uncommon \\
\hline Poaceae & Digitaria setigera Roth & $\mathrm{nen}$ & I & & $\mathrm{x}$ & & $\mathrm{x}$ & Uncommon \\
\hline Poaceae & Digitaria violascens Link & $\begin{array}{l}\text { Smooth } \\
\text { crabgrass }\end{array}$ & $\mathrm{A}$ & & $\mathrm{x}$ & & & Uncommon \\
\hline Poaceae & Digitaria sp. & $\mathrm{ncn}$ & A & & & & $\mathrm{x}$ & Uncommon \\
\hline Poaceae & Dimeria chloridiformis (Gaud.) K. Schum. \& Laut. & $\mathrm{ncn}$ & $\mathrm{E}$ & & & & $\mathrm{x}$ & Common \\
\hline Poaceae & Echinochloa colonum (L.) Link & Jungle rice & A & $\mathrm{x}$ & $\mathrm{x}$ & & & Common \\
\hline Poaceae & Eleusine indica (L.) Gaertn. & Goose grass & A & $\mathrm{x}$ & & & $\mathrm{x}$ & Uncommon \\
\hline Poaceae & Eragrostis amabilis (L.) Wight \& Arnott & Lovegrass & I & & & & $\mathrm{x}$ & Uncommon \\
\hline Poaceae & Eragrostis brownei (Kunth) Nees & $\begin{array}{l}\text { Lovegrass } \\
\text { Indian }\end{array}$ & A & & & & $\mathrm{x}$ & Uncommon \\
\hline Poaceae & Eragrostis pilosa (L.) Beauv.? & lovegrass & A & & & & $\mathrm{x}$ & Uncommon \\
\hline Poaceae & Lepturus repens (Forst. f.) R. Br. & Lesaga & I & & $\mathrm{x}$ & & & Uncommon \\
\hline Poaceae & Oplismenus compositus (L.) Beauv. & Basketgrass & I & & $\mathrm{x}$ & & & Uncommon \\
\hline Poaceae & $\begin{array}{l}\text { Oplismenus hirtellus (L.) Beauv. var. microphyllus } \\
\text { (Honda) Fosb. \& Sachet }\end{array}$ & Basketgrass & I & & & & $\mathrm{x}$ & Common \\
\hline Poaceae & Panicum maximum Jacq. & Guinea grass & A & $\mathrm{x}$ & $\mathrm{x}$ & & $\mathrm{x}$ & Common \\
\hline Poaceae & Paspalum conjugatum Berg. & $\begin{array}{l}\text { Sour paspalum, } \\
\text { T-grass }\end{array}$ & A & $\mathrm{x}$ & & & & Uncommon \\
\hline Poaceae & Paspalum orbiculare Forst. f. var. orbiculare & Ricegrass & A & & & & $\mathrm{x}$ & Uncommon \\
\hline
\end{tabular}




\begin{tabular}{|c|c|c|c|c|c|c|c|c|c|c|}
\hline Poaceae & Paspalum paniculatum $\mathrm{L}$. & $\mathrm{ncn}$ & A & $\mathrm{x}$ & & & & & & Common \\
\hline Poaceae & Paspalum sp. & $\mathrm{nen}$ & A & & & & $\mathrm{x}$ & & & Uncommon \\
\hline Poaceae & Pennisetum polystachyion (L.) Schult. & Mission grass & A & $\mathrm{x}$ & & $\mathrm{x}$ & & $\mathrm{x}$ & & Uncommon \\
\hline Poaceae & Saccharum spontaneum L. & Wild cane & I & $\mathrm{x}$ & & & & $\mathrm{x}$ & & Uncommon \\
\hline Poaceae & Sporobolus indicus (L.) R. Br. & $\begin{array}{l}\text { Smutgrass } \\
\text { Beach }\end{array}$ & $\mathrm{A}$ & $\mathrm{x}$ & $\mathrm{x}$ & & & $\mathrm{x}$ & & Common \\
\hline Poaceae & Sporobolus virginicus (L.) Kunth & dropseed & $\mathrm{I}$ & $\mathrm{x}$ & $\mathrm{x}$ & & & & & Uncommon \\
\hline Poaceae & Zoysia matrella (L.) Merr. ? & Temple grass & I & $\mathrm{x}$ & $\mathrm{x}$ & & & & & $\begin{array}{l}\text { Uncommon, } \\
\text { cult. }\end{array}$ \\
\hline Zingiberaceae & Alpinia speciosa (Wendl.) K. Schum. & Shell ginger & A & & & & $\mathrm{x}$ & & & $\begin{array}{l}\text { Uncommon, } \\
\text { cult. }\end{array}$ \\
\hline DICOTS & & & & & & & & & & \\
\hline Acanthaceae & Barleria cristata $\mathrm{L}$. & $\begin{array}{l}\text { Philippine } \\
\text { violet }\end{array}$ & A & & $\mathrm{x}$ & & & & & Uncommon \\
\hline Acanthaceae & Blechum brownei Juss. F. puberulum Leonard & Yerbas babui & A & & $\mathrm{x}$ & & & & & Common \\
\hline & & $\begin{array}{l}\text { Chichitun, } \\
\text { prickly }\end{array}$ & & & & & & & & \\
\hline Amaranthaceae & Achyranthes aspera L. & chafflower & $\mathrm{I}$ & & $\mathrm{x}$ & & & & & Uncommon \\
\hline Amaranthaceae & Amaranthus viridis $\mathrm{L}$. & Kuletes apaka & A & & $\mathrm{x}$ & & & & & Uncommon \\
\hline Amaranthaceae & Gomphrena serrata L. & Gomphrena & A & & $\mathrm{x}$ & & & & & Common \\
\hline Anacardiaceae & Mangifera indica L. & Mango & A & $\mathrm{x}$ & & & & & & Rare, cult. \\
\hline Annonaceae & Cananga odorata (Lam.) Hook. f. \& Thoms. & Llang-llang & A & & $\mathrm{x}$ & & & & & Uncommon \\
\hline Annonaceae & Guamia mariannae (Safford) Merr. & Guamia & I & & & & & & $\mathrm{x}$ & Common \\
\hline Apiaceae & Centella asiatica (L.) Urb. & $\begin{array}{l}\text { Asiatic } \\
\text { pennywort }\end{array}$ & I & & & & & $\mathrm{x}$ & & Uncommon \\
\hline Apocynaceae & Nerium oleander L. & Oleander & A & $\mathrm{x}$ & & $\mathrm{x}$ & & & & $\begin{array}{l}\text { Uncommon, } \\
\text { cult. }\end{array}$ \\
\hline Apocynaceae & Plumeria obtusa L. & $\begin{array}{l}\text { Plumeria, } \\
\text { frangi-pani }\end{array}$ & A & & $\mathrm{x}$ & $\mathrm{x}$ & & & & Rare, cult. \\
\hline Asteraceae & Bidens alba (L.) DC. & $\begin{array}{l}\text { Beggar's Tick } \\
\text { Masigsig, Siam }\end{array}$ & A & $\mathrm{x}$ & $\mathrm{x}$ & & $\mathrm{x}$ & $\mathrm{x}$ & $\mathrm{x}$ & Abundant \\
\hline Asteraceae & Chromalaena odorata (L.) King \& Rob. & weed & A & $\mathrm{x}$ & $\mathrm{x}$ & & $\mathrm{x}$ & $\mathrm{x}$ & $\mathrm{x}$ & Common \\
\hline Asteraceae & Conyza canadensis L. var. pusilla (Nutt.) Cronq. & Horseweed & A & & $\mathrm{x}$ & & & & & Uncommon \\
\hline Asteraceae & Cyanthillium cinereum (L.) H. Rob. & $\begin{array}{l}\text { Chaguan-Santa } \\
\text { Maria }\end{array}$ & $\mathrm{I}$ & $\mathrm{x}$ & $\mathrm{x}$ & & & & & Uncommon \\
\hline Asteraceae & Eclipta alba (L.) Hassk. & Titima & A & & $\mathrm{x}$ & & & & & Uncommon \\
\hline Asteraceae & Elephantopis mollis HBK. & Papago vaca & A & & & & & $\mathrm{x}$ & & Common \\
\hline
\end{tabular}




\begin{tabular}{|c|c|c|c|c|c|c|c|c|c|c|}
\hline Asteraceae & Mikania scandens (L.) Willd. & $\begin{array}{l}\text { Mile a minute } \\
\text { vine }\end{array}$ & A & & $\mathrm{x}$ & & $\mathrm{x}$ & & $\mathrm{x}$ & Common \\
\hline Asteraceae & Sphagneticola triloba (L.) Pruski & $\begin{array}{l}\text { Masigsig, } \\
\text { Wedelia }\end{array}$ & A & $\mathrm{x}$ & $\mathrm{x}$ & $\mathrm{x}$ & & & & Common \\
\hline Asteraceae & Synedrella nodiflora (L.) Gaertn. & Saigon & A & $\mathrm{x}$ & $\mathrm{x}$ & & $\mathrm{x}$ & & & Common \\
\hline Bignoniaceae & $\begin{array}{l}\text { Tridax procumbens L. } \\
\text { Spathodea campanulata Beauv. }\end{array}$ & $\begin{array}{l}\text { Coat buttons } \\
\text { African tulip } \\
\text { tree }\end{array}$ & A & $\mathrm{x}$ & $\mathrm{x}$ & $\mathrm{x}$ & $\mathrm{x}$ & & & $\begin{array}{l}\text { Common } \\
\text { Common, } \\
\text { cult. }\end{array}$ \\
\hline Bignoniaceae & Tabebuia pallida Miers & $\begin{array}{l}\text { Pink trumpet } \\
\text { tree, Pink } \\
\text { taebuia }\end{array}$ & A & & & $\mathrm{x}$ & $\mathrm{x}$ & & & Rare, cult. \\
\hline Boraginaceae & Cordia subcordata Lam. & Niyoron & I & & $\mathrm{x}$ & & & & & Uncommon \\
\hline Boraginaceae & $\begin{array}{l}\text { Heliotropium procumbens L. var. depressum (Cham.) } \\
\text { Fosb. \& Sachet }\end{array}$ & Huning tasi & I & & $\mathrm{x}$ & & & & & Uncommon \\
\hline $\begin{array}{l}\text { Campanulaceae } \\
\text { (Lobeliaceae) }\end{array}$ & Hippobroma longiflora (L.) G. Don & $\begin{array}{l}\text { Star of } \\
\text { Bethlehem }\end{array}$ & A & & & & $\mathrm{x}$ & & & $\begin{array}{l}\text { Uncommon, } \\
\text { persistent }\end{array}$ \\
\hline Caricaceae & Carica papaya $\mathrm{L}$. & Papaya & A & $\mathrm{x}$ & $\mathrm{x}$ & & $\mathrm{x}$ & & & Common \\
\hline Caryophyllaceae & Cerastium sp.? & $\begin{array}{l}\text { Chickweed } \\
\text { Gagu, }\end{array}$ & A & $\mathrm{x}$ & & & & & & Uncommon \\
\hline Casuarinaceae & Casurarina equisitifolia $\mathrm{L}$. & Ironwood & I & $\mathrm{x}$ & $\mathrm{x}$ & $\mathrm{x}$ & & $\mathrm{x}$ & & Uncommon \\
\hline Celastraceae & Maytenus thompsonii (Merr.) Fosb. & Lulujut & I & & $\mathrm{x}$ & & & & & Rare \\
\hline Clusiaceae & Calophyllum inophyllum L. & Da'og & I & & $\mathrm{x}$ & & $\mathrm{x}$ & & & $\begin{array}{l}\text { Uncommon, } \\
\text { cult. }\end{array}$ \\
\hline Convolvulaceae & $\begin{array}{l}\text { Ipomoeae pes-caprae (L.) Sweet ssp. brasiliensis (L.) v. } \\
\text { Ooststr. }\end{array}$ & $\begin{array}{l}\text { Alalag tasi, } \\
\text { Beach morning } \\
\text { glory }\end{array}$ & I & $\mathrm{x}$ & $\mathrm{x}$ & & & & & Uncommon \\
\hline Convolvulaceae & Ipomoea indica (Burm.) Merr. & $\begin{array}{l}\text { Blue morning } \\
\text { glory }\end{array}$ & I & & $\mathrm{x}$ & & & & & Uncommon \\
\hline Convolvulaceae & Stictocardia tiliifolia (Descr.) H. Hallier & Abubo & I & & $\mathrm{x}$ & & $\mathrm{x}$ & & & Common \\
\hline Cucurbitaceae & Benicasa hispida (Thunb.) Cogn. & Chinese melon & A & $\mathrm{x}$ & & & & & & $\begin{array}{l}\text { Uncommon, } \\
\text { cult. }\end{array}$ \\
\hline Cucurbitaceae & Luffa sp. & $\begin{array}{l}\text { Vegetable } \\
\text { sponge }\end{array}$ & A & $\mathrm{x}$ & & & & & & $\begin{array}{l}\text { Uncommon, } \\
\text { cult. }\end{array}$ \\
\hline Cucurbitaceae & Momordica charantia L & $\begin{array}{l}\text { Almagosa, } \\
\text { Bitter melon }\end{array}$ & A & & $\mathrm{x}$ & & $\mathrm{x}$ & & $\mathrm{x}$ & Common \\
\hline Elaeocarpaceae & Elaeocarpa joga Merr. & Joga & I & & & & & & $\mathrm{x}$ & Uncommon \\
\hline
\end{tabular}




\begin{tabular}{|c|c|c|c|c|c|c|c|c|c|c|}
\hline Euphorbiaceae & Chamaesyce hypericifolia (L.) Millsp. & $\begin{array}{l}\text { Graceful } \\
\text { spurge }\end{array}$ & A & & $\mathrm{x}$ & & & & & Uncommon \\
\hline Euphorbiaceae & Chamaesyce hirta (L.) Millsp. & Hairy spurge & A & $\mathrm{x}$ & $\mathrm{x}$ & & & & & Common \\
\hline Euphorbiaceae & Chamaesyce thymifolia (L.) Millsp. & $\begin{array}{l}\text { Thyme-leaved } \\
\text { spurge }\end{array}$ & A & & $\mathrm{x}$ & & & $\mathrm{x}$ & & Uncommon \\
\hline Euphorbiaceae & Codiaeum variegatum (L.) B1. & Croton & A & & & & $\mathrm{x}$ & & & $\begin{array}{l}\text { Uncommon, } \\
\text { cult. }\end{array}$ \\
\hline Euphorbiaceae & Euphorbia cyathophora Murr. & poinsettia & A & & $\mathrm{x}$ & & & & & Common \\
\hline Euphorbiaceae & Glochidion marianum Muell.-Arg. & Chosga & I & & & & & $\mathrm{x}$ & & Common \\
\hline Euphorbiaceae & Jatropha integerrima Jacq. & $\begin{array}{l}\text { Rose-flowered } \\
\text { Jatropja }\end{array}$ & A & $\mathrm{x}$ & & & $\mathrm{x}$ & & & Rare, cult. \\
\hline Euphorbiaceae & Macaranga thomsonii Merr. & Pengua & $\mathrm{E}$ & & & & & & $\mathrm{x}$ & Uncommon \\
\hline Euphorbiaceae & Manihot esculenta Crantz & Manioc & A & & & & $\mathrm{x}$ & & & Rare, cult. \\
\hline Euphorbiaceae & $\begin{array}{l}\text { Melanopsis multiglandulosa (Reinw. Ex. Bl.) Reichb. } \\
\text { f.\& Zoll. var. glabrata (Muell.-Arg.) Fosb. }\end{array}$ & Alum, alom & $\mathrm{I}$ & & $\mathrm{x}$ & & & & & Uncommon \\
\hline Euphorbiaceae & Phyllanthus amarus Sch.\&Th. & Maigo-lalo & A & $\mathrm{x}$ & $\mathrm{x}$ & & & & & Common \\
\hline Euphorbiaceae & Phyllanthus marianus Muell.-Arg. & Gaogao-uchan & I & & $\mathrm{x}$ & & & & & Uncommon \\
\hline Euphorbiaceae & Phyllanthus saffordii Merr. & $\mathrm{nen}$ & $\mathrm{E}$ & & & & & $\mathrm{x}$ & & Uncommon \\
\hline Fabaceae & Abrus precatorius $\mathrm{L}$. & Rosary pea & $\mathrm{A}$ & & & & $\mathrm{x}$ & & & Uncommon \\
\hline Fabaceae & Alysicarpus vaginalis (L.) DC & $\begin{array}{l}\text { One-leaved } \\
\text { clover }\end{array}$ & A & $\mathrm{x}$ & $\mathrm{x}$ & & & $\mathrm{x}$ & & Common \\
\hline Fabaceae & Bauhinia sp. & Orchid tree & A & & & & $\mathrm{x}$ & & & $\begin{array}{l}\text { Uncommon, } \\
\text { cult. }\end{array}$ \\
\hline Fabaceae & Caesalpinia major (Medic.) Dandy \& Exell & Pakao & $\mathrm{I}$ & & & & $\mathrm{x}$ & & & Common \\
\hline Fabaceae & Canavalia cathartica Thou. & Lodosung-tasi & I & $\mathrm{x}$ & $\mathrm{x}$ & & & & & Common \\
\hline Fabaceae & Chamaechrista nictitans (L.) Moench & $\begin{array}{l}\text { Japanese tea } \\
\text { senna }\end{array}$ & A & & & & & $\mathrm{x}$ & & Common \\
\hline Fabaceae & Crotalaria pallida Ait. & Rattlebox & A & $\mathrm{x}$ & & & & $\mathrm{x}$ & & Uncommon \\
\hline Fabaceae & Delonix regia (Boj.) Raf. & Flame tree & A & & $\mathrm{x}$ & & & & & Rare, cult. \\
\hline Fabaceae & Desmanthus virgatus (L.) Willd. & $\mathrm{ncn}$ & $\mathrm{A}$ & $\mathrm{x}$ & & & & & & Uncommon \\
\hline Fabaceae & Desmodium triflorum (L.) DC & Agsom & A & & & & & $\mathrm{x}$ & & Uncommon \\
\hline Fabaceae & Desmodium sp. & $\mathrm{nen}$ & A & $\mathrm{x}$ & & & & & & Uncommon \\
\hline Fabaceae & Erythrina variegata L. var. orientalis (L.) Merr. & Gaogao & I & & $\mathrm{x}$ & & & & $\mathrm{x}$ & Uncommon \\
\hline Fabaceae & Intsia bijuga (Colebr.) O. Ktze. & Ifit, Ifil & I & & $\mathrm{x}$ & & & & & Uncommon \\
\hline Fabaceae & Leucaena leucocephala (Lam.) deWit & Tangantangan & A & $\mathrm{x}$ & $\mathrm{x}$ & $\mathrm{x}$ & $\mathrm{x}$ & $\mathrm{x}$ & $\mathrm{x}$ & Common \\
\hline
\end{tabular}




\begin{tabular}{|c|c|c|c|c|c|c|c|c|c|c|}
\hline Fabaceae & Macroptilium atropurpureum (DC) Urb. & $\mathrm{ncn}$ & A & $\mathrm{x}$ & $\mathrm{x}$ & & & $\mathrm{x}$ & & Uncommon \\
\hline Fabaceae & Medicago sp. & $\mathrm{ncn}$ & A & & $\mathrm{x}$ & & & & & Uncommon \\
\hline Fabaceae & Melilotus indica (L.) All. & $\begin{array}{l}\text { Yellow sweet } \\
\text { clover }\end{array}$ & A & $\mathrm{x}$ & & & & & & Rare \\
\hline Fabaceae & Mimosa pudica L. & $\begin{array}{l}\text { Sensitive plant } \\
\text { Yellow }\end{array}$ & A & $\mathrm{x}$ & $\mathrm{x}$ & & & $\mathrm{x}$ & & Common \\
\hline Fabaceae & Peltophorum pterocarpus (DC.) Backer ex K. Heyne & poinciana & A & & & & $\mathrm{x}$ & & & Rare, cult. \\
\hline Fabaceae & Pithecellobium dulce (Roxb.) Benth. & Kamachile & A & $\mathrm{x}$ & $\mathrm{x}$ & & $\mathrm{x}$ & & & Rare, cult. \\
\hline Fabaceae & Stylosanthes sp. & Stylo & A & $\mathrm{x}$ & $\mathrm{x}$ & & & $\mathrm{x}$ & & Common \\
\hline Goodeniaceae & Scaevola taccada (Gaertn.) Roxb. & Nanaso, Llat & I & & $\mathrm{x}$ & $\mathrm{x}$ & & $\mathrm{x}$ & & Common \\
\hline Hernandiaceae & Hernandia sonora L. & Nonak, Oschal & I & $\mathrm{x}$ & $\mathrm{x}$ & & & & & Common \\
\hline Icacinaceae & Merriliodendron megacarpum (Hemsl.) Sleumer & Faniok & I & & & & & & $\mathrm{x}$ & Uncommon \\
\hline Lamiaceae & Hyptis capitata Jacq. & Botones & A & & & & & $\mathrm{x}$ & & Common \\
\hline Lamiaceae & Ocmium basilicum L. & Common basil & A & & $\mathrm{x}$ & & & & & Rare \\
\hline Lamiaceae & Ocmium sanctum L. & Yerba buena & I & $\mathrm{x}$ & & & & & & Rare, cult. \\
\hline Lauraceae & Cassytha filiformis L. & Agasi & I & & & & & $\mathrm{x}$ & & Common \\
\hline Loganiaceae & Geniostoma micranthum A. DC. & Majlocjayo & I & & & & & $\mathrm{x}$ & & Uncommon \\
\hline Malvaceae & Hibiscus rosa-sinensis L. var. rosa-sinensis & Hibiscus & A & & $\mathrm{x}$ & $\mathrm{x}$ & $\mathrm{x}$ & & & Rare, cult. \\
\hline Malvaceae & Hibiscus tiliaceus L. & $\begin{array}{l}\text { Pago, Sea } \\
\text { hibiscus }\end{array}$ & I & $\mathrm{x}$ & $\mathrm{x}$ & $\mathrm{x}$ & & & & Common \\
\hline Malvaceae & Malvastrum coromandelianum (L.) Garcke & $\mathrm{nen}$ & A & $\mathrm{x}$ & $\mathrm{x}$ & & & & & Uncommon \\
\hline Malvaceae & Thespesia populnea (L.) Sol. ex Correa & $\begin{array}{l}\text { Banalo, } \\
\text { Rosewood }\end{array}$ & I & $\mathrm{x}$ & $\mathrm{x}$ & $\mathrm{x}$ & & & & Common \\
\hline Melastomataceae & $\begin{array}{l}\text { Melastoma malabathricum L. var. mariannum (Naudin) } \\
\text { Fosb. \& Sachet }\end{array}$ & Gafao, Gafau & I & & & & & $\mathrm{x}$ & & Common \\
\hline Meliaceae & Swietenia macrophylla King & $\begin{array}{l}\text { Honduran } \\
\text { mahogany }\end{array}$ & A & & & & $\mathrm{x}$ & & & $\begin{array}{l}\text { Common, } \\
\text { cultivated in } \\
\text { plantation }\end{array}$ \\
\hline Menispermaceae & Tinospora homosepala Diels & $\mathrm{ncn}$ & $\mathrm{E}$ & & $\mathrm{x}$ & & & & & Rare \\
\hline Moraceae & Artocarpus altilis (Park.) Fosb. & $\begin{array}{l}\text { Lemai, } \\
\text { Seedless } \\
\text { breadfruit }\end{array}$ & A & & $\mathrm{x}$ & & & & & $\begin{array}{l}\text { Uncommon, } \\
\text { persistent } \\
\text { from cult. }\end{array}$ \\
\hline Moraceae & Ficus prolixa Forst. f. & $\begin{array}{l}\text { Nunu Strangler } \\
\text { fig }\end{array}$ & I & & $\mathrm{x}$ & & & & $\mathrm{x}$ & Uncommon \\
\hline Moraceae & $\begin{array}{l}\text { Ficus tinctoria Forst. f.forma neo-ebudarum (Summerh.) } \\
\text { Fosb. }\end{array}$ & Hoda & I & $\mathrm{x}$ & $\mathrm{x}$ & & & & & Uncommon \\
\hline
\end{tabular}




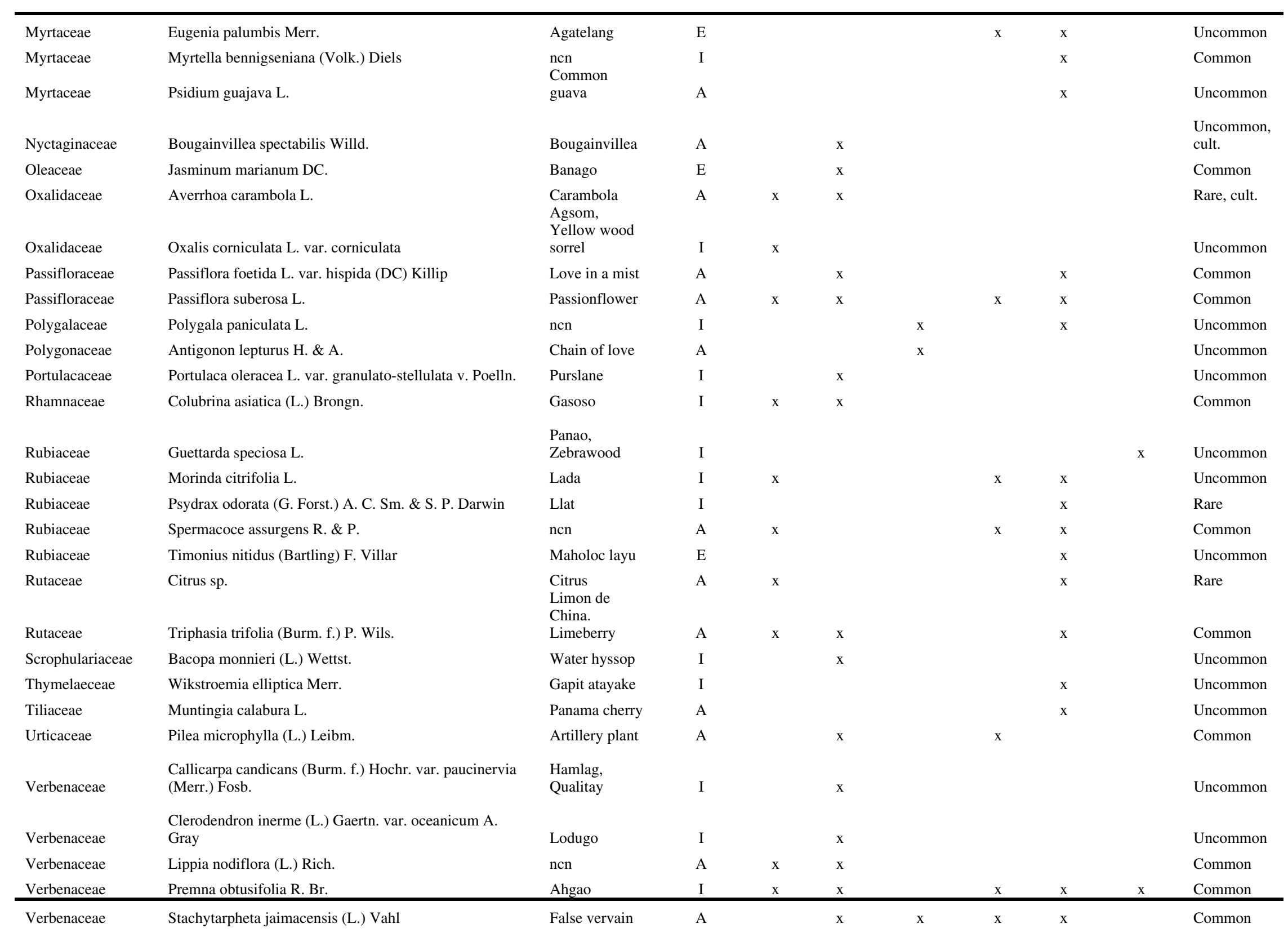




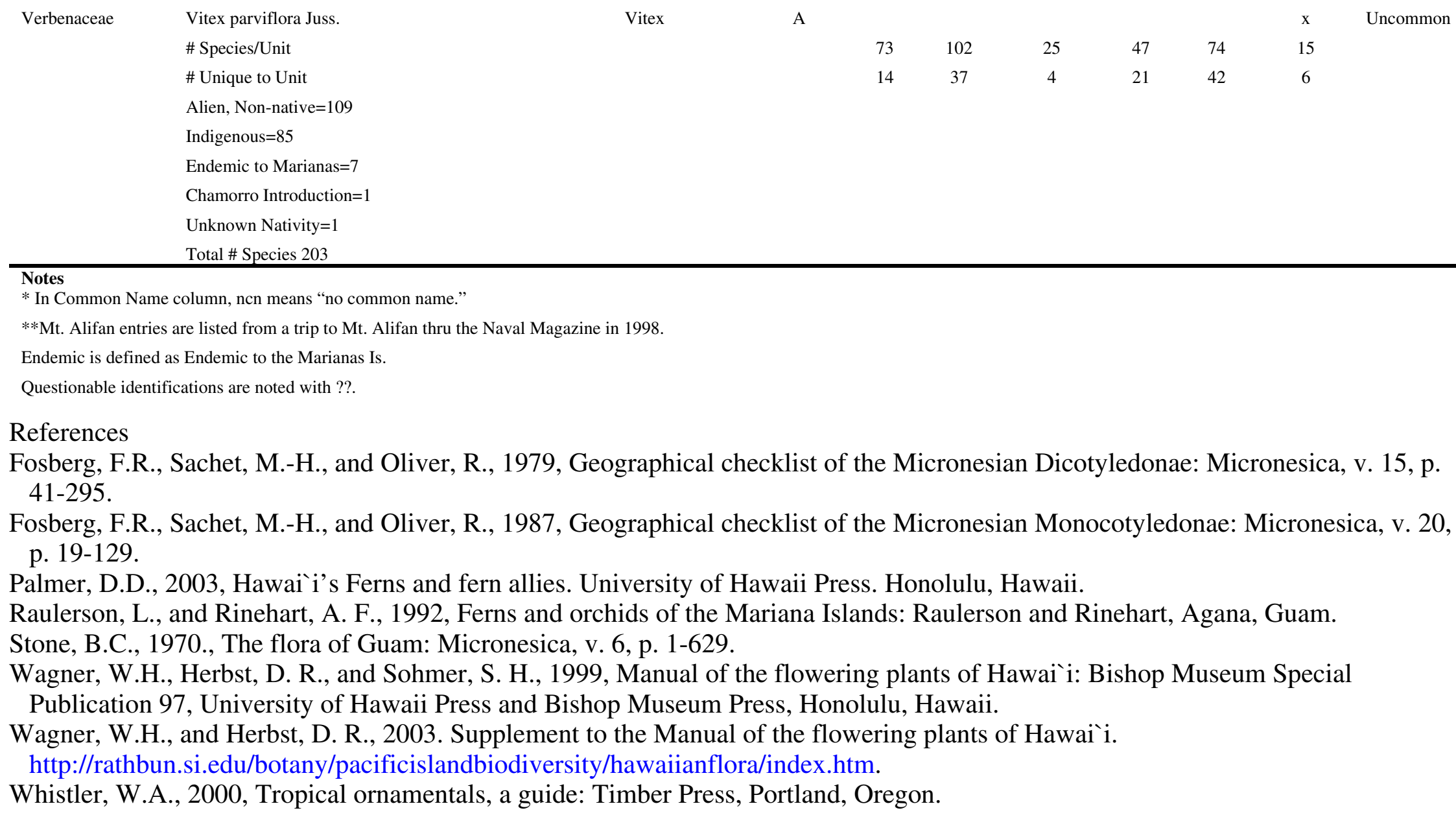

* In Common Name column, ncn means "no common name."

**Mt. Alifan entries are listed from a trip to Mt. Alifan thru the Naval Magazine in 1998.

Endemic is defined as Endemic to the Marianas Is.

Questionable identifications are noted with ??

\section{References}

Fosberg, F.R., Sachet, M.-H., and Oliver, R., 1979, Geographical checklist of the Micronesian Dicotyledonae: Micronesica, v. 15, p. 41-295.

Fosberg, F.R., Sachet, M.-H., and Oliver, R., 1987, Geographical checklist of the Micronesian Monocotyledonae: Micronesica, v. 20, p. $19-129$.

Palmer, D.D., 2003, Hawaîi’s Ferns and fern allies. University of Hawaii Press. Honolulu, Hawaii.

Raulerson, L., and Rinehart, A. F., 1992, Ferns and orchids of the Mariana Islands: Raulerson and Rinehart, Agana, Guam.

Stone, B.C., 1970., The flora of Guam: Micronesica, v. 6, p. 1-629.

Wagner, W.H., Herbst, D. R., and Sohmer, S. H., 1999, Manual of the flowering plants of Hawai i: Bishop Museum Special

Publication 97, University of Hawaii Press and Bishop Museum Press, Honolulu, Hawaii.

Wagner, W.H., and Herbst, D. R., 2003. Supplement to the Manual of the flowering plants of Hawai' i.

http://rathbun.si.edu/botany/pacificislandbiodiversity/hawaiianflora/index.htm.

Whistler, W.A., 2000, Tropical ornamentals, a guide: Timber Press, Portland, Oregon. 


\section{Appendix VI. Vascular plant checklist additions to American Memorial Park (AMME), Saipan, based}

on June 30, 2005 site visit.

\begin{tabular}{|c|c|c|c|c|c|c|c|c|}
\hline R\&R89* & Group/Family & Scientific Name & Synonym & Common Name & Nativity & Cultivated & Abundance & Locality/Notes \\
\hline \multirow{10}{*}{$x$} & Ferns & & & & & & & \\
\hline & Polypodiaceae & Pyrossia lanceolata (L.) Farwell & & & Native (I) & no & common & epiphytic on planted trees \\
\hline & Gynmosperms & & & & & & & \\
\hline & Araucariaceae & Araucaria columnaris (G. Forster) J. D. Hooker & & Cook pine, columnar pine & Alien & yes & uncommon & \\
\hline & Cycadaceae & Cycas circinalis L. & Cycas micronesica & & Native (I) & yes & uncommon & \\
\hline & & Cycas revoluta Thunberg & & Japanese sago palm & Alien & yes & uncommon & multiple sites \\
\hline & Monocots & & & & & & & \\
\hline & Agavaceae & Draceana marginata Lamarck & & Money tree & Alien & yes & uncommon & near bell tower \\
\hline & & Sansevieria trifasciata Prain & & Bowstring hemp & Alien & yes & uncommon & not variegated \\
\hline & & Yucca sp. & & Spanish bayonet & Alien & yes & uncommon & \\
\hline \multirow[t]{8}{*}{$\mathrm{x}$} & Arecacaceae & Cocos nucifera L. & & Coconut palm & Native (I) & yes & common & also growing wild \\
\hline & & Phoenix canariensis Chabaud & & Canary Island date palm & Alien & yes & uncommon & near $\mathrm{VC}$ and gate \\
\hline & & Phoenix roebelenii O'Brien & & Dwarf data palm & Alien & yes & uncommon & near $\mathrm{VC}$ and gate \\
\hline & & Roystonea regia (Kunth) O. F. Cook & & Cuban royal palm & Alien & yes & uncommon & \\
\hline & & Veitchia merrillii (Beccari) H. E. Moore & & Manila palm & Alien & yes & uncommon & near bell tower \\
\hline & Commelinaceae & Tradescantia spathacea Swartz & Rhoeo discolor & Oyster plant & Alien & yes & uncommon & planted in beds \\
\hline & Cyperaceae & Cyperus javanicus Houtt. & Mariscus javanicus & & Native (I) & no & uncommon & Beach south of marina \\
\hline & & Cyperus ligularis $\mathrm{L}$. & & Rocket sedge & Alien & no & uncommon & Beach south of marina \\
\hline \multirow[t]{2}{*}{$x$} & Liliaceae & Hymenocallis littoralis (Jacq.) Salisb. & & Spiderlily & Alien & yes & uncommon & Both cult and naturalized \\
\hline & & Ophiopogon sp. & & Lily turf, mondo grass & Alien & yes & uncommon & Not flowering \\
\hline $\mathrm{x}$ & Poaceae & Cenchrus echinatus L. & & Common sandbur & Alien & no & common & \\
\hline $\mathrm{x}$ & & Chloris sp. & & Finger grass & Alien & no & uncommon & \\
\hline $\mathrm{x}$ & & Cynodon dactylon (L.) Pers. & & Bermuda grass & Alien & yes? & common & in lawns \\
\hline
\end{tabular}




\begin{tabular}{|c|c|c|c|c|c|c|c|c|}
\hline $\mathrm{x}$ & & Dactylotenium aegyptium (L.) Willd. & & Beach wiregrass & Alien & no & common & \\
\hline $\mathrm{x}$ & & Eleusine indica (L.) Gaertn. & & Wiregrass & Alien & no & common & in lawns, near beach \\
\hline $\mathrm{x}$ & & Eragrostis amabilis (L.) Wight \& Arn. & Eragrostis tenella & Love grass & Alien & no & common & weedy in beds \\
\hline \multirow[t]{3}{*}{$\mathrm{x}$} & & Lepturus repens R. Br. & & & Native (I) & no & uncommon & on beach \\
\hline & & Oplismenus compositus (L.) P. Beauv. & & & Native (I) & no & common & $\begin{array}{l}\text { on beach south of marina } \\
\text { on beach and under }\end{array}$ \\
\hline & & Oplismenus hirtellus (L.) P. Beauv.) & & Basket grass & Native (I) & no & common & Casuarina \\
\hline \multirow[t]{2}{*}{$\mathrm{x}$} & & Panicum maximum Jacq. & & Guinea grass & Alien & no & common & Edge of wetland parcel \\
\hline & & Sporobolus virginicus (L.) Kunth & & Beach dropseed & Native (I) & no & common & on beach \\
\hline $\mathrm{x}$ & $\begin{array}{l}\text { Dicots } \\
\text { Acanthaceae }\end{array}$ & Blechum brownei Juss. & & Yerbas babui & Alien & no & uncommon & $\begin{array}{l}\text { on beach and under } \\
\text { Casuarina }\end{array}$ \\
\hline \multirow[t]{5}{*}{$\mathrm{x}$} & Amaranthaceae & Achyranthes aspera $\mathrm{L}$. & & Chichitum, lasogado & Alien & no & uncommon & under Casuarina \\
\hline & Apocynaceae & Allamanda schottii Pohl & & Bush allamanda & Alien & yes & uncommon & in beds \\
\hline & & Nerium oleander $\mathrm{L}$. & & Oleander & Alien & yes & uncommon & \\
\hline & & Plumeria obtusa L. & & Singapore plumeria & Alien & yes & uncommon & multiple sites \\
\hline & & Plumeria rubra $\mathrm{L}$. & & Plumeria & Alien & yes & uncommon & yellow flowered \\
\hline $\mathrm{x}$ & Asteraceae & Bidens alba (L.) DC & & & Alien & no & common & weedy in lawns and beds \\
\hline & & Conyza canadensis (L.) Cronq. Var. canadensis & Erigeron canadensis & $\begin{array}{l}\text { Horseweed } \\
\text { Little ironweed, Chaguan }\end{array}$ & Alien & no & rare & near beach \\
\hline $\mathrm{x}$ & & Cyanthillium cinereum (L.) H. Rob. & Vernonia cinerea & SantaMaria & Alien & no & uncommon & near beach \\
\hline \multirow[t]{4}{*}{$\mathrm{x}$} & & Pluchea indica (L.) Less. & & Indian fleabane & Alien & no & common & on beach south of marina \\
\hline & & Sphagneticola trilobata (L.) Pruski & Wedelia trilobata & Japanese daisy & Alien & yes & uncommon & near Bell tower \\
\hline & & Tridax procumbens $\mathrm{L}$. & & Coat buttons & Alien & no & common & weedy in lawns and beds \\
\hline & Bignoniaceae & Tabebuia heterophylla (A. DC) Britton & $\begin{array}{l}\text { Tabebuia } \\
\text { pentaphylla }\end{array}$ & Pink tecoma & Alien & yes & uncommon & could be $\mathrm{T}$. rosea \\
\hline $\mathrm{x}$ & Caricaceae & Carica papaya $\mathrm{L}$. & & Papaya & Alien & no & common & \\
\hline \multirow[t]{3}{*}{$\mathrm{x}$} & Casuarinaceae & Casuarina equisetifolia $\mathrm{L}$. & & Gago, ironwood & Native (I) & yes & common & $\begin{array}{l}\text { planted near beach, also } \\
\text { growing wild }\end{array}$ \\
\hline & Clusiaceae & Calophyllum inophyllum L. & & Daot, palomaria, kamani & Native (I) & yes & uncommon & \\
\hline & & Clusia rosea N. Jacq. & & Autograph tree & Alien & yes & uncommon & \\
\hline
\end{tabular}




\begin{tabular}{|c|c|c|c|c|c|c|c|c|}
\hline $\mathrm{x}$ & Convolvulaceae & Ipomoea indica (J. Burm.) Merr. & Ipomoea congesta & Blue morning glory & Native (I) & no & uncommon & \\
\hline \multirow[t]{2}{*}{$\mathrm{x}$} & & \multicolumn{2}{|c|}{ Ipomoea pes-caprae (L.) R. Br. Subsp brasiliensis (L.) Ooststr. } & Beach morning glory & Native (I) & no & common & \\
\hline & Cucurbitacaeae & Coccinia grandis (L.) Voigt & & Ivy gourd & Alien & no & common & on trees near wetland \\
\hline \multirow{7}{*}{$\mathrm{x}$} & Euphorbiaceae & Acalypha wilkesiana Muller Argoviensis & & Beefsteak plant, copperleaf & Alien & yes & uncommon & \\
\hline & & Chamaesyce hirta (L.) Millsp. & $\begin{array}{l}\text { Euphorbia hirta } \\
\text { Euphorbia }\end{array}$ & Golondrina, hairy spurge & Alien & no & common & \\
\hline & & Chamaesyce hypericifolia (L.) Millsp. & glomerifera & Graceful spurge & Alien & no & uncommon & \\
\hline & & Chamaesyce prostrata (Aiton) Small & Euphorbia prostrata & Prostrate spurge & Alien & no & uncommon & \\
\hline & & Codiaeum variegatum (L.) Blume & & Croton & Alien & yes & uncommon & \\
\hline & & Jatropha integerrima $\mathrm{N}$. Jacquin & & Rose-flowered jatropha & Alien & yes & uncommon & \\
\hline & & Pedilanthus tithymaloides (L.) Poiteau & & Japanese poinsettia & Alien & yes & rare & $\begin{array}{l}\text { near Bell tower, variegated } \\
\text { form }\end{array}$ \\
\hline \multirow[t]{2}{*}{$\mathrm{x}$} & & Phyllanthus amarus Schum. & & Maigo lalo & Alien & no & common & \\
\hline & Fabaceae & Acacia sp. & & Unknown & Alien & yes & rare & $\begin{array}{l}\text { near Micro beach, large } \\
\text { yellow infl., curled pods }\end{array}$ \\
\hline \multirow[t]{3}{*}{$\mathrm{x}$} & & Albizzia lebbeck (L.) Benth. & & Trongon mames & Alien & yes & uncommon & planted and naturalized \\
\hline & & Cassia javanica L. & & Pink and white shower & Alien & yes & uncommon & \\
\hline & & Cynometra ramiflora $\mathrm{L}$. & & Gulos & Native (I) & yes & rare & planted near VC, one seen \\
\hline \multirow[t]{3}{*}{$\mathrm{x}$} & & Delonix regia (W. J. Hooker) Rafinesque & & Flame tree & Alien & yes & common & planted and naturalized \\
\hline & & Erythrina variegata $\mathrm{L}$. & & Indian coral tree & Native (I) & yes & uncommon & \\
\hline & & Intsia bijuga (Colebr.) Ktze. & & Ifil, ifit & Native (I) & yes & rare & planted near VC, one seen \\
\hline $\mathrm{x}$ & & Leucanea leucocephala (Lam.) deWit & & Tangantangan & Alien & no & abundant & \\
\hline \multirow[t]{3}{*}{$\mathrm{x}$} & & Pithecellobium dulce (Roxb.) Beth. & & Kamachile & Alien & no? & uncommon & \\
\hline & & $\begin{array}{l}\text { Samanea saman (N. jacquin) Merrill } \\
\text { Senna surattensis (N. L. Burman) H. S. Irwin \& }\end{array}$ & & Monkeypod & Alien & yes & uncommon & \\
\hline & & Barneby & Cassia surattensis & Scrambled eggs, kolomona & Alien & yes & uncommon & \\
\hline $\mathrm{x}$ & Hernandiaceae & Hernandia sonora L. & & Nonag & Native (I) & no & common & $\begin{array}{l}\text { Dominant tree in wetland } \\
\text { north of marina }\end{array}$ \\
\hline $\mathrm{x}$ & Lythraceae & Pemphis acidula Forst. & & Nigas & Native (I) & no & uncommon & $\begin{array}{l}\text { on beach/inlet south of } \\
\text { marina }\end{array}$ \\
\hline & Malvaceae & Hibiscus rosa-sinensis L. & & Red hibiscus & Alien & yes & uncommon & \\
\hline $\mathrm{x}$ & & Hibiscus tiliaceus L. & & Pago, sea hibiscus & Native (I) & no & common & \\
\hline
\end{tabular}




\begin{tabular}{|c|c|c|c|c|c|c|c|}
\hline \multirow[t]{5}{*}{$\mathrm{x}$} & & Thespesia populnea (L.) Sol. Ex Correa & Banalo () & Native (I) & no & common & \\
\hline & Meliaceae & Swietenia macrophylla G. King & Honduras mahogany & Alien & yes & uncommon & \\
\hline & Moraceae & Ficus microcarpa (L.) fil. & Chinese banyan & Alien & yes & uncommon & \\
\hline & & Ficus sp. & Unknown species & Alien & yes & rare & one seen, not fertile \\
\hline & Nyctaginaceae & Bougainvillea sp. & Bougainvillea & Alien & yes & uncommon & \\
\hline \multirow[t]{2}{*}{$\mathrm{x}$} & Passifloraceae & Passiflora suberosa L. & Passionflower & Alien & no & common & under Casuarina \\
\hline & Polygonaceae & Cocoloba uvifera (L.) L. & Sea grape & Alien & yes & rare & near Micro beach, one seen \\
\hline $\mathrm{x}$ & Rhizophoraceae & Bruguiera gymnorrhiza (L.) Lam. & $\begin{array}{l}\text { Maglen lahi, many-petaled } \\
\text { mangrove }\end{array}$ & Native (I) & yes & uncommon & $\begin{array}{l}\text { in demonstration wetland, } \\
\text { also natural }\end{array}$ \\
\hline & Rubiaceae & Gardenia sp. & Gardenia & Alien & yes & uncommon & in beds near memorial \\
\hline \multirow[t]{3}{*}{$\mathrm{x}$} & & Morinda citrifolia $\mathrm{L}$. & Lada, Indian mulberry & Native (I) & no? & common & \\
\hline & Scrophulariaceae & $\begin{array}{l}\text { Russelia equisetiformis Schlechtendal \& } \\
\text { Chamisso }\end{array}$ & $\begin{array}{l}\text { Coral plant, firecracker } \\
\text { plant }\end{array}$ & Alien & yes & uncommon & in planter on bldg stairs \\
\hline & Solanaceae & $\begin{array}{l}\text { Solanum lycopersicum L. var. cerasiforme } \\
\text { (Dunal) D. M. Spooner, G. J. Anderson, \& R. K. } \\
\text { Jansen }\end{array}$ & Tomato & Alien & no & rare & near beach \\
\hline
\end{tabular}

*Species presence noted in:

Raulerson, L., and Rinehart, A., 1989, Vegetation of American Memorial Park, Saipan, Mariana Islands: University of Hawaii at Manoa, Department of Botany, Honolulu, Hawaii, Cooperative National Park Resources Studies Unit Technical Report 70,42 p. 